\title{
Ottomans at the Dutch Consular Court
}

\author{
Levantine Confrontations with the Law
}

\section{$1.1 \quad$ Sequesters in 1686}

As mentioned before, virtually all Dutch legislative efforts to regulate legal procedure in the Levant were responses to concrete disputes over jurisdiction that occurred on the ground. A particular challenge to the existing Dutch legal framework presented itself in Izmir in 1685. That year, the States of Holland sent a letter to the Directorate of Levant Trade in Amsterdam, asking for clarification about a grievance brought before them by two Amsterdam-based traders, Gabriël and Pieter Eygels. They stated that 3,o94 lion dollars and 95 aspers belonging to them had been sequestered in Istanbul from the accounts of a partnership between Abraham Vivier and Jan van Ris, both Dutchmen, and Gaspar Chazelles, a French Protestant. It was Vivier who had demanded the sequester, and the Dutch ambassador in Istanbul had complied with the request. ${ }^{1}$ The States of Holland wanted to know from the directorate what their interpretation was of the 1616 article on the jurisdiction of the Aleppo consul, as that specific article had set the rules on litigation involving traders of different nations. ${ }^{2}$

Their first question was if the difference between conflicts within the Dutch community and between Dutch and non-Dutch merchants also applied to a case that affected merchants residing in the Netherlands. Secondly, they also wanted to know how the possibilities of appeal should be understood in this case. In their answer, the directors referred to a report that was issued by some of their members in Amsterdam during a meeting in March 1685, which stated that sequesters between 'the natural inhabitants of the Levant' were permitted, and appeals against them were equally permitted, but only in matters between Dutchmen. ${ }^{3}$ Appeal was explicitly not allowed in cases between Dutchmen and 'Turks' that had been adjudicated in the Levant. ${ }^{4}$ This was a specific clause

1 Heeringa and Nanninga, Bronnen tot de geschiedenis, 2: pp. 249-25o, Directorate of Levant Trade to the States of Holland, Zeeland and West Frisia, Amsterdam, 19/04/1685.

2 For the 1616 regulation, see pp. 93-95.

3 Heeringa and Nanninga, Bronnen tot de geschiedenis, 2: pp. 249-250, Directorate of Levant Trade to the States of Holland, Zeeland and West Frisia, Amsterdam, 19/04/1685, on p. 25o, '[...] naturelle inwoonders in de Levant [...]'.

4 Ibid. 
in the 1616 regulation as well and had in all likelihood been introduced to avoid appeals before Ottoman courts. ${ }^{5}$

The problem was that, on the basis of the 1616 regulation, Gabriël and Pieter Eygels were not able to appeal the sequester, as the involved partnership in Istanbul was not exclusively Dutch. The States of Holland challenged this interpretation on the grounds that the regulation was only concerned with adjudication in the Levant and only applied to situations in which all the parties were physically in the Levant. If no appeal was possible on legal decisions made in the Levant, it was feared that traders in the United Provinces would stop sending money there, which would greatly harm trade. The directors proposed that all legal decisions by Dutch judges on sequesters made in the Levant would be open to a possible appeal, to be adjudicated at the Hof van Holland (see figure 5 ) ${ }^{6}$

The situation of Gabriël and Pieter Eygels and the possibility of multiple interpretations of the 1616 legislation were the motor behind the drafting of a new law in January 1686, which stipulated that sequesters on goods and monies in the Levant would be allowed, but the party demanding one had to provide a sufficient legal reason for it, which had to be presented to the resident or the consul and assessors, depending on jurisdiction. In cases where the person whose goods were claimed resided in the province of Holland, the sequester could not be adjudicated in the Levant but had to be brought before the Court of Holland (Hof van Holland) or the High Council (Hoge Raad), the two central courts of the province of Holland. ${ }^{7}$ If the person whose goods were claimed live in one of the other provinces, the appeal would be treated by the States General. In cases where the person whose goods were claimed lived in the Levant, disregarding whether the claimant resided in the United Provinces or not, the case was to be adjudicated in the Levant by the resident or consul and assessors, 'according to the style and regulations traditionally used and established in these matters.' ${ }^{8}$ Additionally, appeal before a higher judge was allowed on all verdicts and sentences issued in the Levant. If the verdict only concerned people from the province of Holland, or if the defendant in the appeal was from Holland, it was to take place at the Hof van Holland or the

5 For the 1616 regulation, see pp. 93-95.

6 Heeringa and Nanninga, Bronnen tot de geschiedenis, 2: pp. 249-25o, Directorate of Levant Trade to the States of Holland, Zeeland and West Frisia, Amsterdam, 19/04/1685.

7 Heeringa and Nanninga, Bronnen tot de geschiedenis, 2: pp. 251-252, 'Ontwerp-reglement van justitie in de Levant', 17/o1/1686, on p. 251.

8 Ibid., p. 252, '[...] volgens de stijl en de reglementen van outs voor deselve gebruyckelijck en vastgestelt sijnde'. 
Hoge Raad. If the defendant came from another province, then the appeal had to be brought before the States General. All appeals needed to be registered within fourteen days at the court of first instance, and the appeal had to take place within eight months. The consul and resident were ordered to promptly expedite justice. $^{9}$

A resolution issued by the States General on 23 February 1686 turned the draft into law and specified that 'sequesters requested by inhabitants of the Levant, either naturals, Turks or also other [from] other European nations, or the Dutch nation, shall be allowed, and cause effect [...] and the procedures have to be continued immediately and without delay [...] all according to the regulations, and the style in use there [the Levant]. ${ }^{10}$ This is a highly relevant passage in the resolution, which further specified that no appeal was possible against a verdict issued by a Dutch consul regarding a sequester that involved both Dutch merchants and those of other nations, disregarding whether they were European or Ottoman.11

The resolution also declared the sequester made by Vivier void, on the interpretation that the money belonged to a party who resided in Holland. The 1686 resolution was considered an addition to the February 1616 law, which codified the jurisdiction and adjudicating powers of the consul in Aleppo and had been applied to all the Dutch consulates in the Ottoman Empire. ${ }^{12}$ In 1764 , a dispute concerned with liability for several bales of burned cotton was brought before the Dutch consul in Izmir. At the end of the trial, the party sentenced to assume responsibility for the damaged goods wanted to appeal but was informed he could only do so after obeying the verdict issued by the consul and assessors. When that happened, the sentenced party could invoke the 1686 resolution to justify the appeal. ${ }^{13}$ Of all the cases brought before the Dutch consul in Izmir and analysed for this book, this was the only one in

9 Ibid.

10 Heeringa and Nanninga, Bronnen tot de geschiedenis, 2: pp. 252-254, 'Resolutie der Staten-Generaal betreffende de rechtspraak in de Levant', 23/o2/1686, on p. 253, '[...] dat de arresten die versocht sullen werden bij inwoonders in de Levant, hetsij naturellen, Turcken, off oock andere Europische ofte Nederlandtsche natie, sullen mogen werden verleent, ende effect moeten sorteeren [...] dat dien onvermindert aentstonts ende sonder uytstel sal moeten werden voortgevaren met de proceduren [...], alles volgens de reglementen, ende de stijle aldaer gebruyckelijk [...]'.

11 Ibid.

12 Ibid.

13 NACs, $\mathrm{N}^{\circ} 33$, 'Appel der heere Clement, van Sanen, van der Zee \& $\mathrm{C}^{\circ}$ op de sententie', Izmir, 25/05/1764. The case, between the firms of Wijnants \& Cramer of Amsterdam and Ouckama \& $\mathrm{C}^{\circ}$ of Izmir, is analyzed in detail on pp. 162-198. 
which reference was made to a written Dutch law. It shows the continuing importance of the legislation issued in the seventeenth century, particularly as no further Dutch legislation on adjudication in the Levant was issued in the eighteenth century.

\subsection{Central Courts in the United Provinces}

The 1686 law was very timely. Sequester was a common legal means used in commercial disputes, and magistrates often laid legal claims on outstanding balances or consigned goods at the request of creditors to force debtors to take action. This book has focussed on litigation at the consular court of Izmir, thus, at a Dutch court in the Levant. As it was mostly concerned with international trade disputes, sequesters on money and goods were common, and they might take place in faraway territories. It has been argued that, although theoretically possible, commercial disputes were rarely brought before a centralised provincial court in the United Provinces. ${ }^{14}$ Appeals against sequesters were an exception to this, and this had to do with the specific stipulation that these courts were to serve as appeal courts in this matter.

In June 1762, an Armenian merchant based in Amsterdam named Serkis Yazıcıoğlu demanded the aldermen court in Leiden lay a sequester on goods that were in the hands of the merchant Pieter Cauw, former aldermen of that city. These goods belonged to another Armenian trader, Melcum di Aretium, who lived in Izmir. Johan Frederik Mann, who was the chancellor of the Dutch consulate there, had sent di Aretium's goods, which included bales of yarn and cotton, to Cauw on five different ships. Yazıcıoğlu had some open accounts with di Aretium and demanded that the aldermen laid a sequester on goods of equal value to the money di Aretium owed him. Cauw was given the opportunity to respond and answered that he did not have any goods in his possession that had been sent by Mann or that belonged to di Aretium. In December 1762, Yazıcıoğlu petitioned the aldermen for a second sequester, this time on the money he thought was the profit made by Cauw in selling di Aretium's goods. Cauw insisted that he had no dealings with di Aretium, only with Mann. The sequester was permitted, however, and amounted to a value of 5,054 guilders and 16 pennies. When Mann was informed of it, he replied that he was still owed money by Cauw as well in relation to services he had offered in Izmir involving the same goods. Litigation concerning these sequesters ensued in Leiden, leading to a verdict that denied Yazıcıoğlu's claim in April 1764. An 
appeal was made at the Hof van Holland, which confirmed the verdict issued by the aldermen in Leiden. ${ }^{15}$

There was a possibility for a second appeal, and on 28 July 1764, Amsterdam lawyer Pieter Ploos appeared before the Hof van Holland, holding a power of attorney given to him by Serkis Yazıcıoğlu, to appeal the sentence issued ten days earlier. ${ }^{16}$ While the appeal had to be filed at the court that reached the sentence, the appeal itself took place at a higher court, in this case the Hoge Raad, which overturned the verdict in March 1765, for the first time confirming the legitimacy of the sequester. The different judges all provided written reasoning for their decision to allow the sequester, which was based on the evidence that Yazıcıoğlu was di Aretium's creditor and the goods sent to Cauw had indeed belonged to di Aretium, as Yazıcıoğlu claimed. These two conditions were considered sufficiently proven by the court following the admission of written evidence, which must have contained accounts and extracts from business books or commercial correspondence. The question of whether Mann could also lay a claim on the money subjected to the sequester was dismissed by the court, as Yazıcıoğlu had not been aware of this, and he only submitted his claim for a sequester on the money in response to Cauw's declaration that di Aretium's goods were no longer there (but had been sold). ${ }^{17}$

With the sequester considered legitimate, di Aretium and Yazıcıoğlu were expected to settle their dispute before the Hoge Raad. Di Aretium now was the defendant against claims made by Yazıcıoğlu to settle their accounts, something the latter had already demanded explicitly in December 1764 and March 1765 , including a request for an additional payment of interest at $4 \%$. Di Aretium tried to stall the procedure. He claimed the goods and monies on which a sequester had been laid in Leiden did not belong to him and that, consequently, the sequester should be released. But on the other hand, he also expressed his willingness to settle accounts with Yazıcıoğlu, but in Izmir rather than in the United Provinces, 'if necessary before the competent judge there'.18 As the original sequester had been made by Yazıcıoğlu against Cauw, the person who had the goods in his hands, the Hoge Raad felt it was legitimate of di

15 NA, No 3.03 .02 , ('Archief van de Hoge Raad van Holland, Zeeland en (West-)Friesland, 1582-1797') (hereafter NA/Hoge Raad), N ${ }^{\circ} 678$ ('Resoluties tot de sententies', 1763-1768), $19 / 03 / 1765$.

16 NA, $\mathrm{N}^{\circ}$ 3.03.01.o1 ('Archief van het Hof van Holland, 1428-1811') (hereafter NA/Hof), $\mathrm{N}^{\circ} 1729$ ('Residentieboek', 16/12/1762-24/12/1775), f॰ 5 2v-53r, 28/o7/1764.

17 NA/Hoge Raad, $\mathrm{N}^{\circ} 678,19 / 03 / 1765$ and $\mathrm{N}^{\circ} 922$ ('Register der dictums', 1761-1775), 30/o3/ 1765.

18 Perhaps in the hope it would be brought before an Ottoman court. NA/Hoge Raad, ${ }^{\circ} 678$, og/o2/1768, '[...] des noods voor den bevoegden regter aldaar [...]'. 
Aretium to question ownership, but the court decided that di Aretium's ownership was sufficiently proven, considering there was evidence given by one of the toll officials in Izmir and by two fellow merchants in Izmir. The court also found di Aretium's legal efforts hard to reconcile with his denial of ownership of the sequestered goods. ${ }^{19}$

Di Aretium's questioning of ownership seemed to be a manoeuvre to avoid paying his debts more than anything else, and after considering the written evidence and the oral pleas, the judges of the Hoge Raad agreed to maintain their 1765 verdict, reiterating the legitimacy of the sequester and ordering di Aretium once more to settle his account with Yazıcıoğlu, including the payment of interest. ${ }^{20}$ At this point, more than five years had passed since Yazıcıoğlu first attempted to turn to the Dutch legal system to force di Aretium to pay his outstanding debts, and the only thing Yazıcıoğlu had achieved was a sequester and a court order to settle debts. ${ }^{21}$ Including two appeals, he had petitioned three courts, and he had been confronted with the threat of litigation far away in the Ottoman Empire as well. There are no specific indications that Yazıcıoğlu's case was particular, and while a path of litigation such as the one he experienced must have discouraged merchants from seeking recourse to legal action, they also must have felt that sequesters on open accounts or consigned goods abroad were part of the risk attached to international commission trade. The preserved court papers show that neither the physical distance between di Aretium and Yazıcıoğlu nor the fact that they were Armenians were considered as problematic. These were part of the particular circumstances of the case but had nothing to do with its essence, which was a mercantile problem to be resolved according to merchant custom; di Aretium owed Yazıcıoğlu money, and Yazıcıoğlu thus laid a claim on the profits of goods sold in Holland that belonged to di Aretium. The only relevant questions for the judges at the Hoge Raad were about ownership of these goods and the existence of a relationship of debt between di Aretium and Yazıcıoğlu.

This case was rendered more difficult and lengthier because it was brought before the centralised courts of the Hofvan Holland and the Hoge Raad - caused

19 NA/Hoge Raad, N678, o9/o2/1768.

$20 \quad$ NA/Hoge Raad, $\mathrm{N}^{\circ} 922$, o1/03/1768.

21 Such a long duration was not exceptional, and it was a widespread problem. The establishment of specialized courts and the use of summary procedure were two measures that were adopted to ensure speedier sentencing. Based on all the court cases considered in his work on the institutional foundations of long-distance trade, Oscar Gelderblom calculated an average length of 5.5 years. Gelderblom, Cities of commerce, p. 132. For Venice, see Fusaro, 'Politics of justice/politics of trade'. 
by Yazıcıoğlu's desire to appeal a sentence that had not pleased him in the first instance. It is important to note the difference between procedures followed at the higher courts in the United Provinces - which were the formal procedures of a civil trial, presided over by professional judges and pleaded by professional attorneys - and those taking place at the consular court in Izmir, which were specifically designed to adjudicate commercial disputes and which relied on summary procedure and judgment by the consul assisted by peers.

The procedures of litigation at the Hof van Holland (see figure 5) were described in a series of instructions (instructies). The first one was issued by Charles the Bold in 1462 and described the jurisdiction, competence and composition of the court, and it also codified civil procedure. Other instructions followed, but it was only with the issuing of the instructie from $153^{1}$ that the court's functioning was set on firm foundations that remained unchanged until the court's abolition in $1811 .^{22}$ In a similar manner, the Hoge Raad operated on the basis of a large set of instructies - these were issued in $1582 .{ }^{23}$ Civil procedures in these central courts relied on professional judges and were specific. When a case, either in first instance or as appeal, was brought before the Hof van Holland, a particular procedure, the rolprocedure, was followed. First, the plaintiff submitted a request, rekest om mandement, allowing an usher to summon the defendant in court. This request contained the plaintiff's motivation for the litigation. The judges then either allowed it, by writing fiat ut petitur on the request, which happened most of the time, or denied it (nihil ut petitur), in which case the plaintiff could attempt a second time in a hearing before all the judges. If the request was allowed, the writ had to be delivered to the defendant within fourteen days, or three weeks for inhabitants of Zeeland.

The defendant could then decide to either obey the demand or to defend himself. First, he could challenge jurisdiction of the court, ask for delay or provide reasons why the demand should be declared void. Second, he could defend himself regarding the demand itself in his answer or counter-request, which generally contained a formula demanding payment of legal expenses by the plaintiff. Theoretically, the court could sentence at this moment or demand additional information following a temporary verdict. Litigating parties could be asked to provide a memoir containing their legal reasoning or documents (schrifturen) that contained evidence supporting their view and deconstructing the other's view. ${ }^{24}$ In case the defendant provided such

22 Le Bailly, Procesgids, pp. 18-19.

23 Le Bailly and Verhas, Hoge Raad, p. 18.

24 Schrifturen were written documents issued by the litigating parties explaining all the different points of the dispute. 
reasoning to counteract the plaintiff's demand, the litigation entered a phase called enqueste, or evidential procedure, which meant that both parties had to support their viewpoint with evidence, led by one of the judges. Both parties had three months to produce evidence, after which the enqueste ended, and parties were allowed to look at the evidence produced by the opponent, against which they could protest and counter-protest. When this procedure ended, a specially appointed reporter had to control all the pieces of the case, after which he filed a report with the other judges, which started with his own advice for a verdict. The other judges equally provided advice, after which a verdict was reached by a majority of vote. After this, either a final sentence was reached, or it was decided that additional steps were necessary, such as for instance the obligation for parties to come to an agreement. The last element in the litigation was the taxation of the costs and sentencing who had to pay. ${ }^{25}$ The whole procedure was formal, judged by professionals, and parties could be assisted by attorneys. It was also a procedure based on the delivery of written evidence, after which the judges discussed it orally between one another, which was written down in the report.

It is interesting to note that Yazıcıoğlu, as a foreigner, was allowed to bring his case directly before the Hof van Holland but had declined to do so, maybe because he was hoping a case brought before the alderman court against a local trader, in this example Pieter Cauw in Leiden, would be resolved faster and better, through a summary procedure rather than through the more complicated rolprocedure described above. ${ }^{26}$

\section{$1.3 \quad$ The States General and Ottoman Justice}

However, Yazıcıoğlu could have chosen a different path altogether. He could have asked for the sequester of goods belonging to di Aretium in Izmir. A first step would have been to file a claim at the States General, a regular practice with merchants involved in an international dispute, as the States General were the direct superiors of consuls and ambassadors abroad and could instruct them to take certain legal action, such as the sequester of goods. Yazıcıoğlu had not chosen that option, but other merchants who felt wronged did petition the States General. In April 1753, a group of merchants and clothmakers from Amsterdam and Leiden wrote the States General about Mattheus di Ovan, a Persian-born trader who had been living as a merchant in Amsterdam for

25 Le Bailly, Procesgids, pp. 29-41.

26 Although foreigners were allowed to litigate in first instance at a central provincial court, they rarely chose to do so. One of the reasons was that it took longer for these courts to reach a verdict. Gelderblom, Cities of commerce, pp. 126-133. 
twelve years. ${ }^{27}$ Di Ovan had bought cloth, silk and velvet from the petitioning merchants and had these further adapted by the clothmakers in question. The goods were then sent to St. Petersburg, Astrakhan and Izmir. The Persian subsequently disappeared from Amsterdam, still owing more than 45,6oo guilders to that group of merchants and workers for payment of goods and wages. The petitioners immediately took measures to sequester di Ovan's goods but felt the case was so important that it should not be treated 'in the ordinary manner, without support from above. ${ }^{28}$ They demanded the States General to send letters to diplomats in St. Petersburg and Izmir, with a demand to sequester goods there that belonged to di Ovan. The States General consented and issued a resolution to that purpose. ${ }^{29}$

Consul Daniel Alexander de Hochepied in Izmir received a letter on the matter from the States General at the end of June 1753 and he wrote back within three days. He informed them that di Ovan had outstanding credit with two Armenian firms, Malcas di Carabeth and Aretun \& Daniel Qatergığlu, and they both had already been asked to provide more information about di Ovan's credit by the correspondents of the petitioners in Amsterdam and Leiden as well as by other creditors of di Ovan. The Armenian firms refused to comply until they were summoned to appear at the consulate, where they showed their current accounts with di Ovan, which indeed contained more than 5,500 lion dollars belonging to di Ovan as well as a parcel of cloth. Additionally, a Dutch ship that arrived on 28 June, a day after de Hochepied received the first information on di Ovan from the States General, contained two boxes of merchandise that belonged to di Ovan, and sequester was laid on the ship, which the skipper accepted on the condition that it would be resolved before he had fully unloaded. According to the consul's calculations, the total sum of the sequestered assets surpassed 7,000 lion dollars. ${ }^{30}$

27 While the petitioners mentioned the period of twelve years, a petition issued to the Directorate of Levant Trade on a restriction to export ammunition in 1725 contains the name of Matteus di Ovan as merchant in Amsterdam. Heeringa and Nanninga, Bronnen tot de geschiedenis, 3: pp. 203-204, Amsterdam merchants to Directorate of Levant Trade, Amsterdam, 25/o7/1725. For the 1753 petition, see NACs, $\mathrm{N}^{\circ} 3$, 'Request Leonard Lups \& Zoon, Willem Straalman, David Rutgers Jr \& Henrick Buttelman c.s.', Amsterdam, 10/o4/ 1753 .

28 NACs, $\mathrm{N}^{\circ} 3$ o, Request Leonard Lups \& Zoon, Amsterdam, 10/04/1753, '[...] op ordinaire wijze en zonder steun van hogerhand $[\ldots]$ '.

29 Ibid.

30 Heeringa and Nanninga, Bronnen tot de geschiedenis, 3: pp. 259-26o, Consul Daniel Alexander de Hochepied to the States General, Izmir, 30/06/1753. 
The consul, however, feared a successful outcome, because Malcas di Carabeth, Aretun Qatergıŏlu and Daniel Qatergıŏlu were all Ottoman subjects, and de Hochepied thought it would be very complicated to claim di Ovan's debts from the sequestered monies in their accounts, as those would be dealt with by Ottoman justice. De Hochepied wrote that the Ottomans accepted 'neither Frankish laws nor [do] schrifturen have any place according to the law and jurisdiction of the land [i.e., the Ottoman Empire]. ${ }^{31}$ European written evidence, such as business books or schrifturen, were indeed not allowed in Ottoman courts, and there was also no official sanctioning for lying or false testimony. ${ }^{32}$ It is not difficult to understand why Europeans were not happy suing Ottoman subjects in an Ottoman court, as they felt they were at a disadvantage and the outcome was far less predictable for them.

It would, however, be a mistake to simply discard Ottoman courts as not apt for commercial litigation and to take European fear of Ottoman adjudication at face value. The qadi court and the consular court might not have been all that different in their adjudication of commercial disputes. Similar to the Ottoman refusal to accept European written evidence, European consular courts did not admit Ottoman written evidence unless it was translated into a European language. Additionally, the procedures at both courts were in writing. For the consular court, the system of written requests, replies and counter-replies was a written version of the oral summary procedure. For the qadi court, 'the ascendancy of written documents over witness statements' was 'a practical development [...] that was at odds with legal theory'. ${ }^{33}$

When Consul Cornelis Pauw in Aleppo described consular adjudication to the States General in 1615, he wrote that the consuls were following the use of these (Ottoman) lands, which meant they adopted a form of trial 'without admitting any lawyers, attorneys, or time to conduct a trial in writing, and only allowing dragomans to translate [languages of] foreign nations; and having heard the reasons of both parties, the declarations of witnesses who are knowledgeable about the about the affair or any other form of written evidence that

31 Ibid., on p. 26o, 'Want Frankse wetten nog schrifftuuren vinden by het regt en justitie van 't land geen de minste plaetze [...]'.

32 Van den Boogert, The capitulations, p. 45; see also Apellániz, '“You cannot produce a Muslim witness"', pp. 633-648; and, for a later period, Mafalda Ade, 'The Ottoman commercial tribunal in Damascus and the use of testimony and evidence in mixed cases in the 19th century', Quaderni storici, 3 (2016): pp. 649-672. On Islamic legal ideas of distinctions between written and oral evidence, and the superiority of Muslim oral declarations over European written evidence, see Francisco Apellániz, Breaching the bronze wall: Franks at Mamluk and Ottoman courts and markets (Leiden and Boston, 2020). 
mentions the case $[\ldots]$ pronounce an oral sentence. ${ }^{34}$ Pauw's comments are interesting because he was describing summary procedure - a few lines further he referred to it as the 'short style' ('corte stijl') - and he explicitly connected this 'short style' to Ottoman procedures. He was not wrong in doing so, and the main difference with later Dutch consular adjudication in the Levant is that he described a procedure that seems to include physical appearance before court, while eighteenth-century adjudication at the Dutch consular court in Izmir was a written trial, similar in tone and structure to an oral one, allowing similar evidence, but without the obligation for litigants to physically appear before court. It seems then that, initially, Ottoman and European procedures concerning commercial adjudication were closer to one another than they would become later, but essentially, the European written trial kept its summary nature, making the later difference perhaps more about format than content, thus hiding continuing similarities between the two.

In spite of these similarities, in the case of di Ovan, Consul de Hochepied was clear that he wanted to avoid an Ottoman procedure, and he expressed the fear that di Ovan's Dutch creditors would end up paying double. He thought the best course of action would be for the States General to employ Ambassador Elbert de Hochepied, a younger brother of the consul, to obtain a ferman from the Porte ordering the sequestered assets of di Ovan be handed over to the Dutch creditors. ${ }^{35}$ In September 1753, di Ovan's creditors in the United Provinces wrote to the States General again, as they had found out that the two sequestered boxes of merchandise on board the Dutch ship contained three of his sealed business books, which were sent away in an attempt to hide them from scrutiny and to avoid them being used in court. They demanded the consul open these books and have copies made of the extracts that were of relevance to them. The States General agreed. ${ }^{36}$ In the meantime, Elbert de Hochepied did his best in Istanbul, and in December 1753, he informed

34 Heeringa and Nanninga, Bronnen tot de geschiedenis, 1: pp. 468-478, Consul Cornelis Pauw to the States General, Aleppo, 12/og/1615, on p. 469, '[...] de forme van procederen, daerin gouverneren haer de heeren consuls nae de usantie van dese landen, sonder t'admitteren advocaten, procureurs oft tijt om eenige schrifftelijcke processen te formeren, amer alleenlijck H.E. turchemans tot vertalinge van de vrembde natiën; ende aenhoort hebbende de redenen van partijen ten wedersijden, de verklaringe van de getuygen, die van de saecke kennisse hebben, oft eenich ander schriftelijck bewijs, dat daervan soude mogen sprecken, gevisiteert hebbende, geven daerop mondelinge sententie [...]'

35 Heeringa and Nanninga, Bronnen tot de geschiedenis, 3: pp. 259-26o, Consul Daniel Alexander de Hochepied to the States General, Izmir, 30/06/1753.

36 NACs, ${ }^{\circ}{ }^{\circ}$, Request Leonard Lups \& Zoon, Willem Straalman, David Rutgers Jr \& Henrick Buttelman c.s., Amsterdam, 24/o9/1753. 
his older brother in Izmir that he had obtained a ferman, of which he sent a translation. The ferman was to force the Armenian firms to appear at the Ottoman court and to have a hüccet (legal deed) issued there, which would oblige them to deposit the sequestered goods with the Dutch chancery according to agreements made in the capitulations. In case the Armenians denied the presence of di Ovan's assets under their account, it would be easy to find evidence to the contrary, either from declarations by toll officials or in the business correspondence from the Armenian firms. In any case, considering the role Ottoman justice would play, Elbert advised his brother to speak to the Ottoman judge beforehand. ${ }^{37}$ Later writing by Ambassador de Hochepied was more pessimistic; he possessed information that di Ovan was in Astrakhan and feared nothing could be done for his creditors unless they would be able to obtain some official statement from di Ovan. ${ }^{38}$

In 1754, Consul Daniel Alexander de Hochepied ordered for copies of the relevant business documents of di Ovan that had been found in Izmir to be sent back to the United Provinces. Van Lennep and Knipping, holding a power of attorney, and Belcamp, Clement \& van Sanen addressed the parcel to one of the principal creditors in Amsterdam, Willem Straalman. In the meantime, they had been researched 'confidentially, without having changed, obscured, added or left out anything' by three Armenian merchants in Izmir, and these three men were willing to confirm as much under oath. They made copies of the documents, and after this they handed them back to the Dutch chancellor in a bag that was sealed, bound together with a rope and subsequently kept in the chancery. ${ }^{39} \mathrm{~A}$ separate document confirmed that in total, the documents in question numbered thirteen and included balances in Armenian and Italian, a booklet summing up all goods sent to di Ovan from Astrakhan, a contract made with Armenian traders in Astrakhan, several obligations and notes, a business ledger written in Armenian and a letter book containing copies of 232 letters. ${ }^{40}$ As part of the documents had been written in Armenian, it might

37 Heeringa and Nanninga, Bronnen tot de geschiedenis, 3: pp. 267-268, Ambassador Elbert de Hochepied to Consul Daniel Alexander de Hochepied, Istanbul, 16/12/1753.

38 Ibid., p. 268.

39 NACs, $\mathrm{N}^{\circ} 240$ ('Matheus di Ovan, Armeens koopman, uit Amsterdam naar Smyrna gevlucht, 1754'), 'Acte wegens de terug ontfangen Armeense boeken en schriftuuren van Matt di Ovan als meede weegens de versendingh der copije met capt Elias Hendriks', Izmir, 16/08/1754, '[...] vertrouwelijk gedaan zonder het minste te hebben achtergelaten, verandert, verdonkert, vermeerdert nog vermindert [...]'.

$40 \quad \mathrm{NACs}, \mathrm{N}^{\circ} 240$, 'Notta der g'extraheerde Armeense schrifturen de welken met het schip van de capt Elias Hendriks na Amst[erda]m versonden sijn aen den heer Willem Straelman', Izmir, $16 / 08 / 1754$. 
have been unavoidable to demand Armenian traders to assist in translating the relevant material. The role of merchants as co-judges and court experts was crucial in legitimising the merchants' style in court and ensuring its incorporation in the Dutch legal system. Here, they were needed to assess the legitimacy of the written evidence, which was then sent back to the United Provinces, where it could be used in court. ${ }^{41}$

In spite of these efforts, the case remained unresolved, and di Ovan was not found. Further communications on the matter between the States General and Ambassador Elbert de Hochepied several years later referred to new instructions the ambassador had obtained from the Porte, in which the qadi in Izmir was demanded to hand over di Ovan's goods and monies in the hands of the Armenian traders to di Ovan's creditors in the United Provinces. Consul de Hochepied was not pleased, as according to the terms of the instruction, the goods would be delivered only if the consul and all the Dutch traders of Izmir provided security on these goods, a practice that was dangerously close to getting the whole Dutch trading community of Izmir involved in a dispute that did not really concern them. The States General did not see the problem and instructed de Hochepied to comply. ${ }^{42}$

It is not clear whether, and how, the case was resolved, but six years later, the goods belonging to di Ovan remained sequestered. ${ }^{43}$ The cases involving Serkis Yazıcıoğlu and Mattheus di Ovan are telling for a number of reasons. First of all, they demonstrate that merchants did petition the States General for intervention, and the States General was sensitive to these petitions, even when they were made by non-Dutch traders. It confirms, however, the difficulty of a speedy resolution in a context in which summary procedure was not used, with di Ovan's goods still under sequester six years after the initial claim had been made. Perhaps di Ovan's creditors were not able to seek recourse at a local court in the United Provinces, where the procedural context would have led to faster sentencing. It seems likely that, before disappearing, di Ovan made sure not to have left any goods in the United Provinces. He had been careful to consign merchandise to himself and others abroad and attempted to hide his business books. It might have been a conscious strategy to obstruct adjudication in the United Provinces.

41 On legal evidence, see pp. 132-137.

42 NACs, $\mathrm{N}^{\circ} 30$, 'Resolutie Staten Generaal', 23/12/1757.

43 Heeringa and Nanninga, Bronnen tot de geschiedenis, 3: pp. 402-404, Consul Daniel Jean de Hochepied to the States General, Izmir, 15/og/176o. 


\section{Legal Issues of Dutch Protection and Subject Status}

\subsection{Beratl Problems}

In May 1774, Frederik Johan Robert de Weiler, the Dutch chargé d'affaires in Istanbul, sent a letter to the United Provinces in which he objected to a resolution issued by the States General that granted a Greek trader a number of privileges he was not naturally entitled to. ${ }^{44}$ The Greek trader was Demetrio Fronimo, and he acted as an agent in Istanbul and Izmir on behalf of a Greek firm that was established in Amsterdam, the partnership of Brink \& Curmulli. ${ }^{45}$ The resolution had come in response to a request made by them, wanting Fronimo to have the same 'freedoms, liberties and privileges' as the Dutch merchants. ${ }^{46}$ The problem was that they justified their request by arguing Fronimo was an agent for a firm established in Amsterdam, while he was, as a born Greek, an Ottoman subject. De Weiler objected, stating that the original request had falsely portrayed Fronimo as Dutch and the house of Brink \& Curmulli was not officially established in either Istanbul or Izmir. On the other hand, de Weiler admitted that Fronimo was indeed working on commission as an agent for Brink \& Curmulli. De Weiler also sold Fronimo 'an imperial berat by which he [Fronimo] has come under your [States General's] protection, under the moniker of interpreter and in the service of the minister [representative in Istanbul],.47

44 Heeringa and Nanninga, Bronnen tot de geschiedenis, 4: pp. 183-185, Chargé d'affaires Frederik Johan Robert de Weiler to the States General, Istanbul, 17/05/1774.

45 A 1784 registry included Johannes Brink as a Levant trader who was established at the Trippenburgwal near the Nieuwmarkt, as well as Demetrio Curmulli \& $\mathrm{C}^{\circ}$, whose company was registered on the Keizersgracht. Naamregister van alle de kooplieden voornaame handeldryvende of negotiedoende winkeliers en fabricanten der stad Amsterdam (Amsterdam, 1784), pp. 16 and 3 o. In the 177os, Curmulli also had an insurance firm in Venice; see also van den Boogert, 'Ottoman Greeks', pp. 133-138; and Hakkı Kadı, Ottoman and Dutch merchants, p. 249. Johannes Brink, whose diary was kept, was a Greek trader whose original name was Ioannis Pringos. Hasan Çolak, 'Amsterdam's Greek merchants: Protégés of the Dutch, beneficiaries of the Russians, subjects of the Ottomans and supporters of Greece', Byzantine and modern Greek studies, 42:1 (2018): p. 116.

46 Heeringa and Nanninga, Bronnen tot de geschiedenis, 4: pp. 183-185, Chargé d'affaires Frederik Johan Robert de Weiler to the States General, Istanbul, 17/05/1774, on p. 183, '[...] vrijheeden, rechten en priviligiën [...]'; see also Resolutien van de heeren Staaten van Holland en Westvriesland in haar edele groot mog. vergadering genoomen in den jaare 1774, p. 495, 'Missive met sijne bedenkelykheid teegens haar hoog mog. resolutie van 16 maart, op het versoek van Brink en Morré, tot protectie van seekeren Fronimo: commiss', 15/o7/ 1774 .

47 Heeringa and Nanninga, Bronnen tot de geschiedenis, 4: pp. 183-185, Chargé d'affaires Frederik Johan Robert de Weiler to the States General, Istanbul, 17/05/1774, on pp. 183-184, '[...] een keyzerlijk barat, waardoor hij onder de naam van tolk en als in dienst van den 
De Weiler continued that, as a Dutch protégé, Fronimo was exempt from the cizye and enjoyed several other privileges, which were already very advantageous for his principals but that the berat allowed him 'neither to be withdrawn from the supreme authority of his legal lord the sultan, nor to enjoy all such rights, liberties and privileges as the free and national Dutch merchants here do, who are under immediate protection from you as their lords [the States General] and under your same jurisdiction, as if they were in Holland' ${ }^{48}$ De Weiler further mentioned that the French and English did not even allow their Ottoman protégés to trade with France and England, a right Dutch Ottoman protégés did have, and those who had obtained a berat as a Dutch protégé could always forfeit it whenever they wanted. ${ }^{49}$ De Weiler suggested that Brink \& Curmulli had only made the request in order for Fronimo to enjoy the same advantageous fiscal regime as a Dutch merchant, and he advised against granting the request, as it could motivate other protégés to demand the same privileges, which would be harmful for Dutch Levant trade.

Two weeks after de Weiler's letter to the States General, the consul in Izmir, Daniel Jean de Hochepied, sent a letter to the Directorate of Levant Trade in which he agreed with de Weiler. He also referred to earlier problems that occurred after a similar request had been granted to Antonio Zingrilara. Zingrilara had been one of the first Ottoman Greek merchants to establish himself in Amsterdam, where he married a Dutch woman. He successfully petitioned the States General to consider his firm in Izmir as Dutch in 1759, in spite of protests from the Dutch community there, who considered the decision as harmful for their national trade. The Directorate of Levant Trade took the side of the Dutch traders in Izmir, while Zingrilara became an official citizen of Amsterdam in 176o. Zingrilara returned to Izmir in 1765, determined to divorce his Dutch wife and revert back to his Greek roots. The Dutch status of his firm was withdrawn, and Zingrilara's wife had his goods in Holland sequestered, leading to a conflict between Zingrilara and the Dutch that lasted for several years. ${ }^{50}$

minister staande onder uw hoog mogende protectie gekomen [...]' The phrasing reflects the origins of the berat system given to Ottoman interpreters; see pp. 28-29.

48 Ibid., on p. 184, '[...] dog door welke hij nooyt kan nòg worden onttrokken aan 't opperste gezag van zijnen wettigen heere, den sultan, nòg kan gaudeeren van alle zodanige regten, vrijheeden en privilegiën als vrije en nationaele Nederlandsche kooplieden alhier, die onder de immediate protectie van uw hoog mogende als hunne heeren staan en onder hoogstderzelver jurisdictie, even alsof zij in Holland waren [...]'

49 The chargé d'affaires is hinting here at the large Ottoman involvement in Dutch Levant trade that has been discussed on pp. 79-83.

50 Zingrilara had resided in Holland, but returned to Izmir later, hoping to be considered a Dutch national. See van den Boogert, 'Ottoman Greeks', pp. 131-133. Heeringa and 
De Hochepied pointed to the Zingrilara case in order to explain that official Dutch recognition of a Greek firm as Dutch could be highly problematic and cause a great deal of protest from Dutch traders. ${ }^{51}$ Such recognition would cost the Dutch community money, because Greek firms paid more consular duties than Dutch traders. A favourable decision for Fronimo would create a dangerous precedent. ${ }^{52}$ De Hochepied's concerns were shared by his treasurer, Coenraad Schutz, who sent a letter to the Directorate of Levant Trade the same day: 'if such a resolution would take effect, all Greek and other merchants here who have a berat will try, together with their correspondents in the mother country [United Provinces], to bring our nationals to ruin and suppression.'53 The Directorate of Levant Trade took these fears serious and advised the States General to deny Fronimo the request, as 'no dragomans, either ordinary salaried ones [the employees at the consulate] or the honorary ones are permitted to trade as nationals. ${ }^{54}$ Fronimo's request was denied, and he continued to do business as a protégé. Perhaps Brink \& Curmulli felt that the privileges that came with the protégé status were not sufficient, and they might have made the request out of desperation, as Demetrio Fronimo was not doing well commercially - one year after the request had been made, he went bankrupt. ${ }^{55}$

Even if the status of Dutch national merchants, as well as that of the nonMuslim Ottoman traders who had purchased Dutch protection, was clearly defined by legislation, it did not mean that traders did not try to bend the rules to their advantage and approach officials and diplomatic representatives in attempts to obtain privileges. Antonio Zingrilara, for instance, went to

Nanninga, Bronnen tot de geschiedenis, 4: pp. 185-186, Consul Daniel Jean de Hochepied to the Directorate of Levant Trade, Izmir, o3/o6/1774.

Heeringa and Nanninga, Bronnen tot de geschiedenis, 4: pp. 185-186, Consul Daniel Jean de Hochepied to the Directorate of Levant Trade, Izmir, o3/06/1774.

52 Ibid.

53 Ibid., p. 186, C.G.N. Schutz to the Directorate of Levant Trade, Izmir, o3/o6/1774, '[...] wanneer voormelde resolutie effect sorteeren sal, alle met barat voorsiene Griekse en andere kooplieden, hier gestabileert, door hunne correspondenten in het vaderland mede diergelijke naedelige previlegiën tot ruïne en onderdrukkinge onser nationaalen sullen tragten te obtineeren $[\ldots]$ '.

54 Ibid., pp. 189-19o, Directorate of Levant Trade to the States General, Amsterdam, 04/08/ 1774, on p. 189, 'dat het daerenboven nooyt aan eenige draaglieden, hetsij ordinaris gesalarieerde of honoraire, gepermitteert is geweest eenige negotie als nationale te drijven [...]' Ibid., p. 19o. Fronimo continued to trade, although it seems that he left Izmir to start a firm of his own in Vienna. A commercial registry for 1797 contains an entry for 'Demetrio Fronimo und Comp. sudetto Olandese' amongst the list of 'Turkish' subjects settled in Vienna. It seems, thus, Fronimo had managed to keep his protected status. Allgemeiner Handelstands-kalender für das Jahr 1797 welches ein gemeines Jahr von 365 Tagen ist (Wien, 1797), n.p. 
Amsterdam as a Greek trader. After he arrived, he married a Dutch woman and managed to become officially recognised as an Amsterdam citizen. When he went back to Izmir years later, he tried to use his marriage and citizenship in a failed attempt to get his firm accepted as a Dutch national firm. As a result, Zingrilara needed to get an official Ottoman berat, without which the Dutch were not able to protect him. ${ }^{56}$ In the end, he decided to turn away from the Dutch community. He divorced his Dutch wife and rejoined the Greek community. In 1768 he attempted another switch of allegiance by becoming partner in a Dutch firm. A second demand to get Zingrilara recognised as Dutch national failed, after which no further efforts seem to have been taken. ${ }^{57}$

The demands to be recognised as Dutch nationals made by Zingrilara, Fronimo and others were caused by the growing Greek and Armenian Ottoman presence in Amsterdam. Several Ottoman merchants settling in Amsterdam managed to obtain citizen status in Amsterdam, which strengthened their petitions to become Dutch or to become accepted as a partner in a Dutch firm. ${ }^{58}$ The advantages their situation could bring were heavily contested by Dutch traders, who felt they were denied the same beneficial situation, and the Dutch authorities denied Ottoman traders' requests to be considered Dutch and eventually decided to forbid Dutch nationals from accepting Ottoman partners in their firms.

\subsection{Ottoman-Dutch Intercultural Partnerships}

Even though an intercultural partnership was disadvantageous in terms of nationality and protection, it could still be beneficial to all involved traders. The Dutch partner could associate his interests more closely with those of his Ottoman partner, who was more likely to possess better local commercial know-how and a more extensive commercial network in the Levant. While Dutch traders already relied on Ottoman expertise, a formal association through a partnership would motivate the Ottoman intermediary to put his full weight in the transactions he was involved in by becoming a stakeholder in its success. For the Ottoman partner, it could open the possibility of forging closer links with traders in the United Provinces and building up a network that extended well into western Europe. It also opened up the possibility of

56 NACs, $\mathrm{N}^{\circ}{ }_{14}$, Consul Daniel Jean de Hochepied to Ambassador Willem Dedel, Izmir, 16/10/ 1766.

57 Van den Boogert, 'Ottoman Greeks', pp. 131-133.

$5^{8}$ This evolution was analysed by van den Boogert, 'Ottoman Greeks'; see also Çolak, 'Amsterdam's Greek merchants'. 
access to Dutch privileges regarding legal protection and tax exemptions, without having to pay for an official berat.

The first known intercultural Ottoman-Dutch partnership was the association in Izmir between the Dutch firm of Belcamp \& Clement and Panaiotis \& Begler di Joseph, a Greek trading house, established sometime between 1726 and $1730 .{ }^{59}$ Although both di Panaiotis and Begler di Joseph eventually managed to purchase Dutch protection, their association with Belcamp \& Clement might predate this. In his work on Dutch and Ottoman traders, Ismail Hakkı Kadı refers to Ottoman official documents to demonstrate that di Panaiotis received his first berat in May 1731 but also that Begler did not receive one between 1730 and 1740 , a period during which all Dutch berats were renewed. ${ }^{60}$ At a later date, the intercultural partnership was renamed as Belcamp, Begler \& Clement, probably following the departure of Panaiotis, and their firm came up as one of the freighters of a ship sailing with a Dutch captain that had been sent out to buy wheat in Algiers in the late 1740s. The captain had not brought back sufficient wheat, particularly not considering the money he had been given in advance, and as a result, he was summoned for adjudication at the Dutch consular court in Izmir. The consul decided to refer the case to arbitration, with unknown results. ${ }^{61}$

It is interesting to note that, while the legal documents described Begler di Joseph as a 'merchant of our nation', he was not allowed to take the national oath. ${ }^{62}$ The reason given for this was that it would have given him permission to attend meetings held by the Dutch trading community in Izmir and provide him access to Dutch assistance in case of problems with the Ottoman administration. ${ }^{63}$ This shows that, while Ottoman beratlıs were recognised as members

59 In his study on Ottoman-Dutch relations during the embassy of Cornelis Calkoen between 1726 and 1744, Gerard R. Bosscha Erdbrink refers to this association. G.R. Bosscha Erdbrink, At the threshold of felicity. Ottoman-Dutch relations during the embassy of Cornelis Calkoen at the Sublime Porte, 1726-1744 (Ankara, 1975), p. 199. Ismail Hakkı Kadı refers to the partnership as in business by 1730. Hakkı Kadı, Ottoman and Dutch merchants, p. 178.

6o Hakkı Kadı, Ottoman and Dutch merchants, p. 178.

61 NACs, $\mathrm{N}^{\circ} 318$ ('Belcamp, Begler en Clement, Nederlandse kooplieden te Smyrna en Crisoganni en Curmusi, Griekse kooplieden te Smyrna tegen Reyer Hoogtreed, kapitein van het Nederlandse schip Santa Maria, 1747').

62 NACS, $\mathrm{N}^{\circ} 318$, 'Sententie provizioneel weegens t proces tusschen Belcamp, Begler \& Clement, als Hagi Nicolo Gruscheni, en Jami Crumusi, requiranten, en capt Reyer Hoogtreed geacquireerde gepronuncieert', Izmir, o7/04/1747. Di Joseph was labelled with two others as 'koopluijden onzer natie'. Heeringa mentioned Dutch protection given to 'Pannotti Josuf' and 'Joseph di Josuf' in 1719 but mistakenly thought these men were Jewish. Heeringa and Nanninga, Bronnen tot de geschiedenis, 2: p. 155 .

63 Hakkı Kadı, Ottoman and Dutch merchants, p. 179. 
of the Dutch trading community with regards to their legal and (mostly) their fiscal status, they remained foreigners who paid higher consular duties. ${ }^{64}$ Not allowing protégés to take the national oath was part of the Dutch attempt to keep foreigners at a distance from the Dutch trading community following the regular complaints made by Dutch nationals to the consul in Izmir about the position of Ottoman protégés, which they considered as too advantageous. ${ }^{65}$ At an unknown date, the partnership ended. Begler di Joseph went to Trieste, where he was held in 1755 because he went bankrupt, leaving behind considerable debts with Dutch traders. It caused a stir, and four years later, after an intervention on di Joseph's behalf by a Greek in the service of the dey of Algiers, he was let go as the creditors agreed there was nothing to be recovered anymore. ${ }^{66}$

At first, Dutch authorities saw commercial partnerships between Ottoman and Dutch traders as a way to make money. In 1741 the States General formally allowed such partnerships but introduced additional tariff rates of $2 \%$ on the value of imports and exports of all goods belonging to such a partnership that were shipped on Dutch vessels and $1 \%$ of goods that were shipped on foreign vessels. ${ }^{67}$ Several Ottoman-Dutch partnerships came into being in the following years, apparently functioning well, such as the one between Manolaki di Panaiotis, a Greek Ottoman who had purchased French protection, and Jacob de Vogel in 1760. Manolaki di Panaiotis was the son of the man who had partnered up with Belcamp, Begler and Clement, while Jacob de Vogel was a merchant from Rotterdam who had originally come to Izmir in 1757 as a scribe. ${ }^{68}$ By August 1767 the partners had decided to separate, but the split was not amicable. ${ }^{69}$ Later, the former partners met at the French consular court, with di

64 For the national oath, see pp. 57, 81 and 99-100.

65 See also pp. 300-307.

66 News on the bankruptcy was published, for instance, in The Whitehall evening post, or London intelligencer, 13-15/11/1755. News about the resolution was sent in a letter from Bartold Douma van Burmania, the Dutch envoy in Vienna dated 25 February 1759, in Verzameling van geheime brieven, 9: n.p. A claim of one of the Dutch creditors is preserved in the archives of the Dutch envoy in Vienna. NA, $\mathrm{N}^{\circ} 1.02 .05$ ('Archief van de Legatie bij de Duitse keizer'), $\mathrm{N}^{\circ} 134$ ('Stukken betreffende een vordering van Cornelis van der Oudermeulen, koopman in Amsterdam, op Begler de Joseph in Triëst, gewezen Grieks koopman in Smyrna, 1755-1757').

67 Scheltus, Groot placaatboek, 7: pp. 1588-1589, 'Resolutie van de Staaten Generaal, waar by vastgesteld word een generaal reglement over alle de schaalen van de Levant, Salonica daar onder begreepen', 27/06/1741.

68 Jacob de Vogel from Rotterdam was not related to the de Vogels of Amsterdam.

69 Heeringa and Nanninga, Bronnen tot de geschiedenis, 4: p. 1226, Thomas de Vogel to Thomas de Vogel Junior, Amsterdam, o7/08/1767; and ibid., pp. 200-201, Directorate of Levant Trade to C.G.N. Schutz, Amsterdam, 21/o3/1775. 
Panaiotis a defendant against the firm of Jan Ackerman \& Zoon in Amsterdam, from whom Jacob de Vogel had received a power of attorney to act as plaintiff. ${ }^{70}$

In 1766 , the consul, treasurer and assessors had confirmed that only men who were Dutch nationals were allowed to take the Dutch national oath and that neither foreign traders nor foreign clerks or scribes could take it, which was a measure to prevent these foreigners from paying lower consular duties. ${ }^{71}$ On 16 January 1769 , the national oath was formally extended to include the promise that 'no one of the land [Ottoman Empire], subjects of the great lord or other foreigners would carry an interest, directly or indirectly, in their trade firms or commission houses', formally forbidding partnerships between Ottoman and Dutch traders. ${ }^{72}$

In 1775 , di Panaiotis decided to denounce his former business partner, who had been shipping goods belonging to Ottomans under his own name, breaking existing regulations as well as the Dutch national oath. Di Panaiotis further complained about poor treatment from his former partner, but this was considered of no concern to Dutch authorities. ${ }^{73}$ Jacob de Vogel was summoned to defend himself in a meeting in Izmir, during which he admitted that he indeed received goods from foreigners in commission but claimed that this was not

$70 \quad$ NACs, $\mathrm{N}^{\circ} 356$ ('Proces stukken tusschen gebroeders de Vogel \& Comp als procureurs van Jan Ackerman \& Zoon in Amsterdam \& Ml Kiriaco di Panajotti \& Comp, begonnen 24/o1/ 1775 gaande tot $\left.06 / 11 / 1775^{\prime}\right)$.

$71 \quad$ NACS, $\mathrm{N}^{\circ} 162$, 'Notulen van consul, tresorier en assessoren weegens diverse orders \& reglementen vande heeren directeuren', Izmir, 14/11/1766.

72 Joannes van der Linden, Groot placaatboek, vervattende de placaaten, ordonnantien en edicten, van de hoog mog heeren Staaten Generaal der Vereenigde Nederlanden en van de edele groot mog. heeren Staaten van Holland en Westvriesland; mitsgaders van de edele mog. heeren Staaten van Zeeland (Amsterdam, 1796), 9: p. 1296, 'Resolutie van de Staaten Generaal, houdende verbod aan de ingeseetenen van deesen staat, in de Levant geëtablisseert, om zig in hunnen handel of commissien met de onderdanen van de Grooten Heer of met andere vreemden te mogen associeeren', 16/o1/1769, '[...] en zonder dat er iemand van het land, onderdaanen van den Grooten Heer, of andere vreemden in onse commissien direct of indirect mogen zyn geinteresseert'.

73 Heeringa and Nanninga, Bronnen tot de geschiedenis, 4: pp 200-201, Directorate of Levant Trade to C.G.N. Schutz, Amsterdam, 21/03/1775. Di Panaiotis had litigated against de Vogel before the Dutch consular court between 1770 and 1773 in an attempt to claim money he felt Jacob de Vogel owed him in relation to an earlier affair that concluded the partnership of the two men. The consul's sentence dismissed the claim made by di Panaiotis, who intended to bring an appeal before the Dutch ambassador, the competent court. The ambassadorial archives do not contain such an appeal case. NACs, $\mathrm{N}^{\circ} 225$ ('Proces tusschen Ml Kco di Panajottis \& Jacob de Vogel aengaende eene avania van 1770 tot 16 maert 1773'), 'Sententie in faveur van Jacob de Vogel \& teegens Manuel Kiriako di Panaiotti', Izmir, 16/o3/1773. 
forbidden. It caused a debate amongst merchants, and several agreed with de Vogel, according to the chancellor because they were in the same situation. In his letter to the Directorate of Levant Trade, the chancellor wrote that de Vogel's fate could not be decided and that he waited for the judgment of the directors. It did not stop him from choosing a side, and he labelled Jacob de Vogel as a 'very honest man, known as such to everyone', while he described di Panaiotis as 'that Greek, known to everybody as a very bad person' with a 'filthy and evil character. ${ }^{74}$

The Directorate of Levant Trade, however, was not convinced of de Vogel's defence. In his written statement, de Vogel maintained that he had not broken the national oath, but he did not mention the addition made to the national oath in January 1769 , which stipulated that no Ottoman subjects were allowed to have a commercial interest in the trade of a Dutch national if it was the latter who had paid the (lower) consular duties and other taxes. The problem was that de Vogel had indeed lent his name to hide transactions in goods belonging to Ottoman traders, who tried to avoid the higher tariff on their goods when shipped on Dutch ships and sent to the United Provinces. At the same time, this merchandise, officially Dutch, was exempt from certain Ottoman taxes according to the capitulations. De Vogel was not the only trader involved in this case, and the illegal practice of using Dutch firms as cover for Ottoman trade harmed both Dutch commercial interests and the Ottoman treasury, and the directors wanted the consul to put a stop to this abuse. ${ }^{75}$ In response to the matter, the States General issued a regulation in 1769 which prohibited partnerships between Dutch merchants in the Levant and Ottoman subjects or any other foreigners active there. ${ }^{76}$ The case dragged on for years, with consul, assessors and treasurer concluding in a meeting on the matter held in December 1775 that, although the addition to the national oath did not prevent associations between Dutch and foreigners, the practice of using Dutch firms to cover up Ottoman commercial activities was illegal. ${ }^{77}$

74 Heeringa and Nanninga, Bronnen tot de geschiedenis, 4: pp. 204-205, C.G.N. Schutz to the Directorate of Levant Trade, Izmir, 18/05/1775, on p. 205, '[...] dat hij een dooreerlijk man is en daarvoor ook bij een yder bekent is [...]' and 'het vuyl en boosaardig character van die Griek, die van een yder voor een seer slegt subject bekent is [...]'.

75 Heeringa and Nanninga, Bronnen tot de geschiedenis, 4: pp. 215-216, Directorate of Levant Trade to Consul Daniel Jean de Hochepied, Amsterdam, 19/o9/1775.

76 Van der Linden, Groot placaatboek, 9: p. 1296, 'Resolutie van de Staaten Generaal', 16/o1/ 1769 .

77 Heeringa and Nanninga, Bronnen tot de geschiedenis, 4: pp. 218-219, 'Vergadering consul, thesaurier en assessoren', Izmir, 18/12/1775. 
It is interesting to note that Dutch merchants themselves played a role in resolving this problem, as the assessors were chosen yearly amongst the Dutch traders of Izmir. ${ }^{78}$ The commercial experience of traders was considered as a crucial element in commercial litigation, and their involvement as assessors was not exceptional. ${ }^{79}$ Still, Dutch authorities realised that conflicts of interest might occur. The merchant community in Izmir was small, and merchants were competing with one another over commissions. This is why assessors had to swear an oath of neutrality. Assessorship rotated, but some merchants were able to hold on to the position for years, giving them a great deal of power in the Dutch community. In all cases studied for this book, the consul followed the advice given by the assessors. On the other hand, the assessors were kept in check by the rotation system, the oath they had taken and by the consequences their reputation could suffer if it was perceived that they might have been motivated by personal interest. Additionally, an assessor with poor judgment might find himself in court as defendant on day, judged by his peers. The importance given to the legal reasoning provided by the assessors, who were Dutch nationals, was also balanced by the recurrent use of expert reports. These experts were always chosen from amongst different trading communities.

A potential conflict of interest was most likely one of the reasons why, in an earlier letter, the directors had made an enquiry about the possibility of having 'neutral merchants', by which they meant other Europeans or even Ottomans, investigate whether Jacob de Vogel could have taken the national oath 'with a pure conscience. ${ }^{80}$ Correspondence between the directors and the consul makes it clear that the national oath was not intended to prevent Dutch houses in Izmir from taking commissions from foreign firms, but only to stop the practice of letting Ottoman traders in Izmir use a Dutch merchant's name for shipping or receiving goods in an attempt to avoid taxes. In August 1777 the consul became tired of the whole discussion and wrote in frustration to the States General that 'never anything is clear enough for our gentlemen merchants here, and they always try to find excuses [...] some continue to load

78 See pp. 91 and $94-100$.

79 See for instance Kessler, A revolution in commerce.

8o Heeringa and Nanninga, Bronnen tot de geschiedenis, 4: pp. 215-216, Directorate of Levant Trade to Consul Daniel Jean de Hochepied, Amsterdam, 19/og/1775, on p. 215, '[...] neutraele lieden [...]' and '[...] met een suijver gemoed [...]'. While the practice of using foreign experts was normal enough for the directors to not make such an enquiry, this situation was different, as it considered an opinion on the national oath and not on the merchants' style. 
and receive goods under their name, on behalf of foreigners and rayas living in Izmir'.81

In April 1778, the Dutch chancellor in Izmir visited the firms of the assessors as well as that of Esaias Fercken, a merchant originally from Liège, asking them whether they agreed to pay consular duties and dragomanagie as if they were foreigners in cases where they were handling goods of foreigners. ${ }^{82}$ They all agreed, and they also recognised that any troubles with Ottoman fiscal authorities resulting from this practice would fall under each firm's personal responsibility, which meant that the Dutch consul would not interfere to help and the Dutch community as a whole would not pay. ${ }^{83}$ The problem was finally put to rest at a meeting of the Directorate of Levant Trade in Amsterdam, who suggested the addition of another phrase to the text of the national oath, namely that the merchants promised to accept all avanias resulting from the practice of name-lending to Ottomans at the Ottoman tax administration and to deal with them individually, without seeking recourse to the consulate or to any money in the common register. ${ }^{84}$

In the context of avanias, the new addition to the national oath meant that if the practice of name-lending would lead to additional taxation by the Ottoman authorities, it was an individual problem. The word avania reflects the European idea that any additional taxation not specified in the capitulations was a form of extortion. ${ }^{85}$ Europeans were extremely fearful that individual behaviour led to collective consequences - a fear that is very reminiscent of the functioning of the medieval mechanism of collective responsibility. ${ }^{86}$

81 Heeringa and Nanninga, Bronnen tot de geschiedenis, 4: pp. 240-242, Consul Daniel Jean de Hochepied to the States General, Izmir, o9/o8/1777, on p. 240, 'Nooyt is er yets klaars genoeg voor sommige onser heeren cooplieden alhier en zij tragten altoos eenige capties te vinden $[\ldots]$ sommige gaan daarop voort met goederen op hunne naam te laaden en te ontfangen voor de vreemde en rayas hier te Smirna woonagtig [...]'. 'Raya', or 'Re'âyâ', was the term for a tax-paying member of the lower class in the Ottoman Empire but was often also used to refer to Ottoman non-Muslim subjects who paid the haraç and was thus synonymous with zimmi. See van den Boogert, The capitulations, pp. 43 and 189.

82 Dragomanagie was a tax of $2.5 \%$ of the value of consular fees payable on goods and was used to pay the ordinary dragomans who worked as interpreters. Hakkı Kadı, Ottoman and Dutch merchants, p. 157.

83 Heeringa and Nanninga, Bronnen tot de geschiedenis, 4: p. 254, 'Extract registers kanselarij Smyrna', Izmir, 14/04/1778.

84 Heeringa and Nanninga, Bronnen tot de geschiedenis, 4: p. 26o, 'Vergadering directeuren', Amsterdam, 29/o7/1778. In August, this suggestion was communicated to the burgomasters of Amsterdam. Ibid., pp. 26o-263, Directorate of Levant Trade to the burgomasters, Amsterdam, [?]/o8/1778.

85 See pp. 232 and $308-312$.

86 See pp. 207-208 and $311-312$. 
It is, of course, understandable that European traders in the Ottoman Empire preferred no collective consequences and less taxation, but that, of course, does not necessarily mean that additional taxation by Ottoman authorities was in any way unjust.

By the time Jacob de Vogel was defending himself before his peers, partnerships between Dutch and Ottoman traders had already been forbidden, which was probably the reason why Ottomans had started to ship their goods under the names of Jacob de Vogel and several other Dutch traders in the first place. It seems the first concrete steps leading to restrictions on intercultural partnerships had come from Consul Daniel Jean de Hochepied, who expressed his doubts about allowing any Ottoman partner into a Dutch firm in a letter to Holland in 1766 . He feared these practices would lead to the whole firm passing as Dutch, enjoying all commercial advantages that came with the Dutch status. De Hochepied stated that 'our national meetings would be swarming with all sorts of people' and claimed that 'our interests would be mingled with theirs', something he felt would be a bad evolution. ${ }^{87}$ While the association between di Panaiotis and de Vogel had come into being before his tenure, his letter was inspired by events that were happening at that time. A young man named Isaac Beaune was expected to arrive in Izmir from Amsterdam, and he had agreed to form a partnership with the Armenian trader Malcas di Carabeth. ${ }^{88}$ Beaune, the consul argued, surely expected to benefit from the protection offered to him as a Dutch subject and all the national privileges that derived from the payment of the consular duties. The consul would not be able to decline Beaune protection, as he was Dutch, but he was not willing to extend the same status to his Armenian business partner, because he would not allow national protection to foreigners.

The consul refused to validate any Ottoman-Dutch partnership, because he felt that the interests of the national and the foreigner would become inseparable, and the Ottomans would certainly consider the firm as Dutch. This, de Hochepied felt, would harm Dutch national interests. He seemed to be afraid that Beaune would not be the only foreign merchant to benefit from the Dutch privileges but also 'many of his friends and acquaintances', perhaps again a reference to the practice of Ottomans shipping under a Dutch name. ${ }^{89}$

87 NACs, $\mathrm{N}^{\circ}{ }_{14}$, Consul Daniel Jean de Hochepied to unknown addressee, Izmir, o3/o7/1766, '[...] de nationale vergaderingen zouden krioelen van alle soorten mensen' and '[...] souden onse intresten met de haere gemengt werden [...]'.

88 For Isaac Beaune, see also pp. 101 and 230.

89 NACs, $\mathrm{N}^{\circ}{ }_{14}$, Consul Daniel Jean de Hochepied to the States General, Izmir, 19/o8/1766, '[...] veele zijnder vrienden en kennissen [...]'. 
But for de Hochepied, the most detrimental consequence was the exposure an Ottoman-Dutch firm would get in case the Ottoman was summoned before an Ottoman court. Europeans generally held a negative attitude towards the option of litigation before an Ottoman court, where they were 'vulnerable to suffering many difficulties and even great disadvantages. ${ }^{90}$ While the European idea that Ottoman courts were somehow less reasonable and equitable in their sentencing was false, there was also the general European fear that the Ottomans might ignore at will some of the privileges granted in the capitulations. One of these privileges was legal autonomy, and the inclusion of Ottoman partners in Dutch firms and a subsequent summoning of an Ottoman partner at an Ottoman court might provoke a challenge to this authority. De Hochepied concluded that allowing di Carabeth and Beaune to form an association would harm the Dutch community as a whole, while it would only be beneficial to di Carabeth, a foreigner. Furthermore, allowing the business association meant that di Carabeth would receive similar advantages as a Dutch Ottoman beratlı without paying for them. ${ }^{91}$ This, of course, went against recirprocity and mutual interest, cornerstones of the merchants' style.

Beaune, convinced of di Carabeth's value as a partner, insisted, but when he wanted to take the Dutch national oath after his arrival, this was refused unless he was willing to trade in his name alone without di Carabeth as partner. Beaune did not want to comply, but when his name appears later in official documents, it is as an independent trader, which suggests that in the end, he might have had little choice if he wanted to remain part of the Dutch trading community of Izmir. ${ }^{92}$ The national oath had evolved from a controversial instrument that no trader wanted to take in the seventeenth century, to a mechanism that could be used to pressure Dutch nationals into respecting the consul's decisions in the eighteenth century. ${ }^{93}$

The objection Dutch authorities had towards intercultural partnerships was partially justified by the damage done to the national interest, the protection of which was a crucial consular task. But this did not mean that such partnerships did not work or that no merchants tried to form Ottoman-Dutch partnerships after Beaune and di Carabeth. Several others, mostly between

9o Ibid., '[...] daer door aen veel strubbelingen en selffs aen groot nadeel werden blootgesteld $[\ldots]$.

91 For the beratlıs, see pp. 61-64.

92 See p. 230.

93 For the national oath, see pp. 57, 81 and 99-100. 
Ottoman Greeks and Dutch merchants, were known to exist. ${ }^{94}$ It has been argued that intercultural partnerships in Izmir were less important than the totality of returning transactions between Dutch and local traders, one-off or repeated, particularly when considering the total volume of trade. ${ }^{95}$ This does not diminish the importance of looking at intercultural partnerships and the manner in which they were dissolved. Several of these partnerships ended on bad terms, such as the one between di Panaiotis and de Vogel, but hardly any evidence exists amongst the Izmir court cases that suggests the partners blamed each other for having a different origin, religious adherence or nationality. In court, traders only blamed each other for personal behaviour that went against the reason and equity of the merchants' style. In the rare cases where di Panaiotis was called 'that Greek' and Jews were referred to negatively, such references without exception came from chancellor and consul, not from fellow merchants. The only trader to attempt a legal argumentation on the lines of national background was Gerrit van Brakel, who constructed a discourse in which he complained about the unfair treatment of Europeans in comparison to Ottomans, but the consul dismissed his argumentation completely. ${ }^{96}$

The lack of 'national' animosity between merchants of different origins is also reflected in the fact that Dutch consular jurisdiction offered a sufficient legal framework within which disputes between business partners of different origins could be settled. This is an argument in favour of the idea that intercultural trade could develop and be fostered through the development of a set of increasingly international norms and habits regulating the business relationships between merchants. A merchant needed to remain trustworthy, wellreputed and financially sound. His background was not so important, except when it gave him an unfair advantage, as that would go against the commercial custom of reciprocity and mutual interest. This is why Ottoman traders who had associated themselves with Dutch nationals or who had obtained Dutch protection either through the purchase of a berat or through requests made to the States General in the United Provinces only came under criticism from their Dutch fellow traders in the context of discussions on fiscal and legal advantages.

94 Various other partnerships are mentioned in Hakkı Kadı, Ottoman and Dutch merchants, pp. 182-197; and Artunç, 'The protégé system', pp. 17-18.

95 Hakkı Kadı, Ottoman and Dutch merchants, p. 183.

96 See the case discussed on pp. 291-30o. 


\section{The Most Cosmopolitan Form of Quarrelling}

\subsection{Gerrit van Brakel's Bill of Exchange}

Non-Muslim Ottoman traders who had purchased berats figured frequently amongst the parties involved in commercial litigation before the Dutch consular court, next to a small number of Ottoman traders who had not purchased a protected status. The difference was that the Dutch Ottoman protégés could be tried by a Dutch court as defendant while Ottomans without such status did not have that legal privilege and could only appear in the court records as plaintiffs against Dutch nationals or Dutch protégés. It was as plaintiff that the Greek firm of Alexander \& Sottira was involved in a dispute that was tried at the Dutch consular court in 1769. In May that year, they filed a request for restitution from the Dutch merchant Gerrit van Brakel, who had issued a bill of exchange of 939 guilders to Alexander \& Sottira, to be paid out by correspondents in Rotterdam. The bill of exchange bounced and came back to van Brakel, who was asked to redeem it as well as pay for interest and expenses. ${ }^{97}$

The court documents do not make any mention of a protected status for the Greek partners, and as Ottoman subjects, they could have attempted litigation before the qadi in Izmir. Perhaps they had declined to do so because the European-style bill of exchange was not commonly used in the Ottoman Empire and litigating on the basis of non-Ottoman exchange law before a qadi court seemed much less practical than seeking recourse to the Dutch consular court. There was an Ottoman-style bill of exchange, the suftaja, which was a letter of credit that differed from the European bill because repayment was in the same currency as the original payment. Its payment, however, was sanctioned by the state, and qadi courts were used for disputes involving suftaja payments. ${ }^{98}$ It is also possible that Alexander \& Sottira preferred to avoid a qadi court because Islamic law forbade loans with interest, and it was commonly known that the European-style bill of exchange indirectly charged interest by

97 NACs, $\mathrm{N}^{\circ} 343$, 'Request van Alexander en Sottira weeg: een geret. wisselbrief aen G: v Brakel van f939', Izmir, o8/o5/1769.

98 Abraham L. Udovitch, Partnership and profit in medieval Islam (Princeton, 1970), pp. 268269; Eliyahu Ashtor, 'Banking instruments between the Muslim east and the Christian west', Journal of European economic history, 1 (1972): pp. 554-562; and Şevket Pamuk, A monetary history of the Ottoman Empire (Cambridge, 2000), p. 84. For Islamic financial instruments, see chapter six on 'The medieval hawale: The legal nature of the suftaja and other Islamic payment instruments', in Benjamin Geva, The payment order of Antiquity and the Middle Ages. A legal history (Oxford and Portland, 2011), pp. 252-306. 
including it in the exchange rate. ${ }^{99}$ In their claim, Alexander \& Sottira were specifically asking for an interest payment from van Brakel, a claim that was perhaps impossible to ask at a qadi court. In the late Middle Ages, Islamic legal scholars had come to object to the bill of exchange on the grounds that it placed liability on the payee, who received the money, as well as on the person that had accepted the bill - the taker. This double liability gave an advantage to the payee because, the bill of exchange was considered a loan, and Islamic law had it that full liability for a loan was with the borrower or payee alone - and thus not shared. 100

Van Brakel defended himself by stating that the protest of the bill had arisen out of the refusal by Alexander \& Sottira to contribute to the damages on certain goods, which had been sent to Holland in a joint operation by Gerrit van Brakel and Alexander \& Sottira. Each party had benefitted, and since the transaction, the partnership between the Dutchman and the Greek traders had been dissolved, with an oral agreement that each party would carry a part of the potential damage and loss. As this had not happened, van Brakel answered the claim from his former Greek partners by petitioning the consul, treasurer and assessors of the Dutch nation to grant him restitution of 200 bordaten in recompense for the unpaid damages on the transaction. ${ }^{101}$

A week after van Brakel's reply, the consul, treasurer and assessors issued a temporary verdict in which they sentenced van Brakel to deposit the value of the protested bill of exchange at the chancery and to comply with 'the

99 Formally, Christianity also forbade loans with interest, the pope still sanctioning it in 1745. See, for instance, Jerry Z. Muller, The mind and the market - Capitalism in modern European thought (New York, 2002), p. 9. Restrictions, however, did not mean the practice did not exist, and, similar to the Christian world, Islamic societies had systems of borrowing with interest. See, for instance, Şevket Pamuk, 'Institutional change and longevity of the Ottoman Empire', Journal of interdisciplinary history, 35:2 (2004): pp. 231-232; and Ronald C. Jennings, 'Loans and credit in early seventeenth century Ottoman judicial records: The sharia court of Anatolian Kayseri', Journal of the economic and social history of the Orient, 16:2-3 (1973): pp. 168-213.

100 Murat Çizakça, Islamic capitalism and finance. Origins, evolution and the future (Cheltenham and Northampton, MA, 2011), pp. 47-48.

101 NACS, $\mathrm{N}^{\circ} 343$, 'Request antwoord van Gerrit van Brakel aen Alexander \& Sotira weeg: een geretourneerde wissel van f939', Izmir, 11/05/1769. It is unclear what a 'bordaat' actually was, but in all likelihood, it was cloth with hems. It was a regularly imported item from the Levant to the United Provinces, see René Bekius, 'Avet Jeremias. Een Levantijns koopman in achttiende-eeuws Amsterdam', in De Nederlands-Turkse betrekkingen, eds. Maurits van den Boogert and Jan Jonker Roelants (Hilversum, 2012), p. 67. 
exchange law and custom in this type of case.'102 The bill of exchange was a financial instrument necessary for conducting international business, as it allowed for payment in different currencies, and it was a contract involving three or four parties in two countries. With the growing recognition of its importance for trade, and the growing realisation that trade was important for the economic development of states, an exchange law developed that codified aspects of international merchant custom into local, and later also 'national', legal statutes and ordinances.

Since the Middle Ages, bills of exchange had been crucial instruments in international trade, because they allowed for the financial remittance of profits on transactions abroad. From the early eighteenth century onwards, bills could be endorsed to other traders, a possibility that had turned them into negotiable commodities. ${ }^{103}$ They were regulated through written law, the socalled 'exchange law'. As the bill of exchange was an international device, the laws regulating their handling were international, and already in 1629, it was argued in the United Provinces that exchange law was uniform and valid in all Christian countries. ${ }^{104}$ Various legal scholars, such as Laurens Pieter van der Spiegel and Carl Günther Ludovici, attributed a special place for exchange law in their analysis of the sources for commercial law, and exchange law occupies an interesting position between written law and merchant custom, not unlike bankruptcy procedures. ${ }^{105}$

The importance of the bill of exchange as a credit instrument in international trade was not disputed, and as such, all regulations surrounding it

102 NACs, $\mathrm{N}^{\circ} 343$, 'Vonnis van consul, th:r $\mathrm{x}$ assessooren tot het depositeeren van de waerde van een met protest geret: wisselbrief van f939 aen Gerrit van Brakel', Izmir, 19/05/1769, '[...] het wisselregt $\mathrm{x}$ gebruijk in sulke gevallen [...]'.

103 About the evolution of the endorsement, a practice that may have started in the late sixteenth century and had become common by the middle of the seventeenth century, see Geoffrey Poitras, The early history of financial economics, 1478-1776 - From commercial arithmetic to life annuities and joint stocks (Cheltenham, 2000), pp. 231-232; and Raymond de Roover, L'évolution de la lettre de change XIVe-XVIIIe siècles (Paris, 1953), pp. 220-221.

104 Martin van Velden, Fondament vande wisselhandeling: onderrichtingh ghevende van alle voornaemste wisselen van Christenrijck, so van trates remessen, vergelijcking van prysen, verscheyden commissien te vormen (Amsterdam, 1629). On the use of the bill of exchange in the Ottoman Empire, see Maria Christina Chatziioannou and Gerlina Harlaftis, 'From the Levant to the city of London: Mercantile credit in the Greek international commercial networks of the 18th and 19th centuries', in Centres and peripheries in banking. The historical development of financial markets, eds. Philip L. Cotrell, Even Lange, and Ulf Olsson (Abingdon, 2016), pp. 13-40. On the history of the bill of exchange, see the first chapter in Trivellato, The promise and peril of credit, pp. 19-35.

105 See pp. 106-109 and 129. 
were fundamentally international, but it would be a mistake to assume that exchange law was a clear and simple example of international law. There were local varieties, and disputes on bills of exchange referred to the locality of the competent law. Several cases brought before the Hoge Raad are discussed in an eighteenth-century compilation of the private notes of Willem Pauw, counsellor at the Hoge Raad and later its president. Fifty-eight of the disputes were concerned with bills of exchange, and Pauw mentions the use of Amsterdam exchange law in fifteen cases and Rotterdam exchange law in six. Local exchange laws of other Dutch cities are mentioned in other cases. ${ }^{106}$ Amsterdam exchange law took a central place because that city played a crucial role in the traffic in bills of exchange. ${ }^{107}$

Because exchange law was so well-developed, it is not a coincidence that one of the very few references made to a particular law in any of the trial documents preserved in the archives of the Dutch consulate in Izmir was to it. In that context, it seems logical that the dispute between Alexander \& Sottira and Gerrit van Brakel was solved quickly. Alexander \& Sottira filed their petition, van Brakel provided a written reply and the Greek traders provided a counterreply, after which a sentence instructed van Brakel to obey the law. ${ }^{108}$ There were eleven days between the initial claim and the verdict. But the dispute was not resolved, as Gerrit van Brakel did not feel satisfied with its outcome, because no mention was made of the merchandise he felt he was entitled to. He remarked that he would have no problem subjecting himself to the verdict, but only if the opponents 'were subjects of any European sovereign, who would also be judged according to European laws, but as they were subjects of the land [Ottoman Empire], who only wanted to profit from European rights and laws for as long as these matched their interests, but who, when they considered it otherwise, would call upon the rules and laws of these lands [Ottoman Empire]'.109 It is important to note that in one of the few instances

106 C.H. Bezemer, 'Tussen wal en schip. Het wisselrecht ten tijde van de Republiek der Verenigde Nederlanden', $B W$-krant jaarboek, 29 (2015): pp. 22-23.

107 See, for instance, Phoonsen, Wissel-styl tot Amsterdam; and Wagenaar, Amsterdam in zyne opkomst, 4: pp. 425-446. For an early modern study on exchange law, see Johann Gottlieb Heineccius, Grondbeginselen van het wisselrecht (Middelburg, 1774).

108 NACs, $\mathrm{N}^{\circ} 343$, 'Vonnis van consul, th:r $\mathrm{x}$ assessooren tot het depositeeren van de waerde van een met protest geret: wisselbrief van f939 aen Gerrit van Brakel', Izmir, 19/05/1769.

109 NACs, $\mathrm{N}^{\circ} 343$, 'Antwoord van Gerrit van Brakel op het vonnis tot depositeeren van f939 weegens Alex \& Sottira', Izmir, 22/05/1769, '[...] menschen waaren van eenige Europese souverainen, die ook na Europese wetten konde geoordeeld werden, maar onderdanen van dit land zijnde, die maar van de Europese regte $\mathrm{x}$ wette willen profiteeren, voor zoo lange zulx met hare interesse overeenstemd, maar het contrarie ziende, zij zig op de regten, en wetten deezer landen komen te beroepen [...]'. 
in which a concrete and codified law could be invoked, van Brakel attempted to delegitimise the verdict that was based upon it by pointing to the fact that his opponents were not Europeans. Because the merchants' style upon which trade disputes were settled generally was international, the different nationality of an opponent could not be invoked as a counter-argument to a verdict. But this was different, exactly because of the verdict's reliance on codified law.

Van Brakel's remark was not atypical for the way European traders looked upon Ottoman merchants who sought recourse to European legal institutions, and it shows a more general discomfort with the idea that some traders attempted forum shopping for individual advantage, an action that contradicted the reciprocity of the merchants' style. ${ }^{110}$ Van Brakel's argument did not help him, and the consul insisted that he had to comply with exchange law, deposit the money and, in case he wanted to prosecute Alexander \& Sottira for the bordaten, make a separate claim within twenty-four hours. The consul was sure that van Brakel would file a separate claim and ordered Alexander \& Sottira to deposit the bordaten at the Dutch chancery.111

Alexander \& Sottira requested immediate execution of the verdict instead, but van Brakel reiterated his earlier appeal. ${ }^{112}$ The language he adopted became quite emotional, not uncommon in litigation. ${ }^{113} \mathrm{He}$ labelled Sottira as 'a thief of honour and an ungrateful creature', complaining 'riffraff had better access [to a favourable sentence] than an honest man.114 The terms of the verdict were not suitable for the honest merchant that van Brakel considered himself to be, as they were those given to bankrupts, which he was not. ${ }^{115}$ With these comments, the case was steered into a familiar direction - using attacks on the opponent's reputation as a central legal argument. What was unusual, though, was that van Brakel took it one step further when he started to question the

110 For the practice of forum shopping, see pp. 14 and $308-312$.

111 NACS, $\mathrm{N}^{\circ} 343$, 'Antwoord van Gerrit van Brakel op het vonnis tot depositeeren van f939 weegens Alex \& Sottira', Izmir, 22/05/1769; and 'Recieff van ter deposito ontfangen 200 p.s bordaten van Alex: \& Sottira', Izmir, 27/05/1769.

112 NACS, $\mathrm{N}^{\circ} 343$, 'Request van Alex:r \& Sottira tot versoek van executie van het vonnis tot de deposito der f939', Izmir, 29/05/1769; and 'Origineele missive van Gerrit van Brakel in ant op die van den heere consul van heeden aen mij cancel geschreeven', Izmir, 30/05/1769.

113 See pp. $185^{-188 .}$

114 NACS, $\mathrm{N}^{\circ} 343$, 'Origineele missive van Gerrit van Brakel in ant op die van den heere consul van heeden aen mij cancel geschreeven', Izmir, 30/05/1769, '[...] Sottira die eerdief, en ondankbaar creatuur [...]' and '[...] een canailie meer ingang heeft als een braaf mens [...]'.

115 Ibid. Van Brakel's pejorative use of 'bankrupt' is hardly surprising considering the long association between fraud and bankruptcy - even though legally that automatic association was disappearing; see pp. 199-208. 
consul's decisions. ${ }^{116} \mathrm{He}$ expressed his surprise at the twenty-four-hour period he was given to comply and suggested that it was not fully honest, but this time, he addressed his letter directly to the chancellor, who he asked to be his protector, and not to the consul. He reminded him of the case between Jacques Forêt and Dirk Knipping, in which he had acted as plaintiff on Forêt's behalf, the time it took to resolve the matter and the leniency then granted to Knipping: 'how I was treated then, verify it with your own conscience.'117 He concluded that he would not obey the verdict but bring his 'equitable and righteous case' to competent judges, who would 'not need 24 hours but only one minute to satisfy me.'118 $\mathrm{He}$ concluded his letter to the chancellor with a threat: 'they are rayas, slaves of the Great Lord, and I will make these gentlemen dance differently'.119

The consul, treasurer and assessors read van Brakel's letter and expressed their surprise. The consul claimed that it did not matter who the involved parties were, the problem was with a bill of exchange, so exchange law applied no matter where the case was taken to. Should it have been brought before a court in Holland, Daniel Jean de Hochepied continued, van Brakel would already have been judged for not paying. The consul gave him forty-eight hours to pay, otherwise the Dutch community would treat him as an 'unwilling and disobedient person.'.120 This meant he might lose his status of Dutch national in Izmir and the protection of the Dutch authorities. It would be communicated as such to the other European chanceries and the Ottoman authorities too. De Hochepied added that 'it does not bother us what Sottira is, and we have to be content if the people of the land [Ottoman Empire] are willing to accept our law, and not their own' - a phrase that confims that Sottira might very well have chosen to litigate before a qadi court. ${ }^{121}$ The consul concluded his letter by reminding van Brakel that he had already created problems when he owed some money to the Dutch treasury, which had forced the consul to threaten

116 A similar manoeuvre ended badly for the Sicilian merchant Gasparo Marchetti; see pp. $259-264$.

117 NACs, $\mathrm{N}^{\circ} 343$, 'Origineele missive van Gerrit van Brakel in ant op die van den heere consul van heeden aen mij cancel geschreeven', Izmir, 30/05/1769, '[...] hoe ben ik behandelt, gaat het in u eyge conscientie na [...]'.

118 Ibid., ‘[...] mijn billike en regtvaardige zaak [...]' and '[...] geen 24 uure maar een minuut tijd om mij direct te voldoen [...]'.

119 Ibid., '[...] t zyn reaas slaven van den grooten heer zal ik die messieurs anders doen danze'.

$120 \mathrm{NACs}, \mathrm{N}^{\circ} 343$, 'Twee copijen der brieven van van Brakel \& de heere consul', Sediköy, 30/05/ 1769 , '[...] als onwillige en ongehoorzaame [...]'.

121 Ibid., '[...] wat of Sottira is doet ons niets, en wij moeten al wel te vreeden zijn, als de lieden van het land aan ons regt wille koomen, en zig niet aan het hare houden [...]'. 
him with a sequester of his goods, and by stating that he wished honourable, young and esteemed men would not let affairs get that far. He regretted that van Brakel had written such an insulting letter to his own judges. ${ }^{122}$ Confronted with these threats, van Brakel complied under protest but pursued his claim against Alexander \& Sottira before the Dutch consular court in Izmir. ${ }^{123}$

The remainder of the case documents deal with van Brakel's claim and focus on the dissolution of the partnership between him and Alexander \& Sottira. The chancellor issued a declaration confirming that in April 1769, a notarial deed ending the partnership had been passed before him and several witnesses. It did not, however, specify the concrete terms of the dissolution, which had been agreed upon verbally and which included the possible reimbursement of the bill of exchange under scrutiny, in case it would bounce. A solution had also been discussed verbally about the division of the damages on the goods that the partnership had sent to the United Provinces. ${ }^{124}$ Chancellor Mann's declaration served van Brakel better than Alexander \& Sottira, who denied that verbal agreements on the dissolution of their partnership with van Brakel had been made, and they suggested that van Brakel had manipulated the chancellor's written statement. ${ }^{125}$ Van Brakel replied that the chancellor was an official who was bound to the truth by an oath, which was a valid legal instrument in Dutch law, and his declaration should be evaluated by the consular judge and not by the plaintiff. Van Brakel made the additional comment that he was willing to abandon his claim if Alexander \& Sottira swore under oath, with their hands on the Bible and in the presence of the Dutch chancellor and the Greek bishop, that no verbal agreement had been made between themselves and van Brakel. ${ }^{126}$ It was a very strong request, given the tight connection between religion, truth and natural law, and it clearly demonstrates how seriously oaths were taken as instruments to establish the truth. ${ }^{127}$

122 NACS, $\mathrm{N}^{\circ} 343$, 'Twee copijen der brieven van van Brakel \& de heere consul', Sediköy, 30/ 05/1769; and 'Origineele missive van den heere consul aen van Brakel tot het depositeeren offte andere dispositie', Sediköy, or/o6/1769.

123 NACs, $\mathrm{N}^{\circ} 343$, 'Request van Gerrit van Brakel beloften van het deposito der g'ordonneerde f939 voor een geretourneerde wissel', Izmir, o2/06/1769; 'Recieff van de ter deposito ontfange waerde van $\mathrm{f} 939$ van Gerrit van Brakel weegens Alexander \& sottira', Izmir, 05/06/ 1769; and 'Replicq van Gerrit van Brakel aen Alex:r \& Sottira', Izmir, 24/07/1769.

124 NACs, $\mathrm{N}^{\circ} 343$, 'Declaratie van mij can: weegens het gepasseerde tusschen van Brakel \& Alexander \& Sottira aengaende de reservatie van eene nog loopende wisselbrieff', Izmir $02 / 08 / 1769$.

125 NACs, $\mathrm{N}^{\circ} 343$, 'Replicq d'Alex:r en Sottira teegens van Brakel met verwerping der declaratie van mij Cancell:', Izmir, o8/o8/1769.

126 NACs, $\mathrm{N}^{\circ} 343$, 'Replicq van Gerrit van Brakel aen Alexander \& Sottira', Izmir, 12/o8/1769.

127 For the role of the oath as legal evidence, see pp. 134-135. 
A similar remark pointing to the importance of religion can be found in a 1760 dispute in which Herman van Coopstad in Rotterdam demanded Knipping \& Ouckama in Izmir have the monies they still had of Marcus Koch, an arms dealer in Liège, sequestered in order to recover debts the latter had to van Coopstad. Knipping \& Ouckama answered that they would comply, but they also remarked that they were not surprised, as 'one has never something good to expect from those who renounce their god and their faith', the reason why they had advised van Coopstad not to engage in business with them. ${ }^{128}$ In a world in which a person's reputation was one of his most important business assets and the trust placed in a fellow trader was a necessary step for engaging in business, questioning someone's change in religious affiliation was not so strange. A change of religion might have been considered as evidence of a lack of loyalty, which was a crucial part of commercial reputation. If one was willing to renounce one's god, one might just as easily discard business partners.

When Chancellor Mann and two witnesses went to the house of Alexander \& Sottira to ask whether they were willing to take an oath, they were met with a refusal. ${ }^{129}$ Van Brakel's demand must have been familiar to Alexander \& Sottira, considering they were Ottoman subjects. The oath was a common practice in Ottoman courts as a means of evidence as well. ${ }^{130}$ Now that the case would not be judged on the basis of the oath, a declaration before God, which would have to be accepted as the truth by Gerrit van Brakel, the consul and assessors decided to request the opinion of other merchants, in other words, peers would have to provide advice based on merchant custom. French, Italian, English and Ragusan merchants were consulted, and all concurred that, in cases where a partnership was dissolved and a general closure of accounts had been accepted by both parties, as in this case, no party could go to a court trying to obtain a different settlement concerning matters that had occurred before the dissolution. ${ }^{131}$ The consul and assessors agreed with this opinion, and the sentence was simple: neither party got what they wanted, as the bill of exchange had to be given back to van Brakel, and he had to bear the damages' costs incurred on the joint shipment of goods. Both parties were to pay

128 NACs, $\mathrm{N}^{\circ} 490$, Knipping \& Ouckama to Herman van Coopstad, Izmir, $31 / 01 / 1760$, '[...] men heeft nooit iets goets te wachten van iemand die syn god x gelooff versaackt [...]'.

129 NACs, $\mathrm{N}^{\circ} 343$, 'Acte tot het vraagen van een eed aen Alexander \& Sottira van diferente pointen', Izmir, 31/o8/1769.

130 Ergene, Local court, pp. 64-65.

131 NACS, $\mathrm{N}^{\circ} 343$, 'Parere weegens de differentie van Alex:r \& Sottira met Gerrit van Brakel', Izmir, o1/og/1769. 
half of all the expenses made. ${ }^{132}$ Van Brakel accepted, but Alexander \& Sottira made their intention to appeal the verdict before the competent court very clear. ${ }^{133}$ It is unclear whether the Greek firm filed an appeal and, if so, at which court. Theoretically, appeals against consular verdicts should be adjudicated by the Dutch ambassador in Istanbul, but Dutch records contain no further references to this dispute.

Even though the sentence did not put the full blame on Gerrit van Brakel, his discourse troubled the consul, and not for the first time. A few years earlier, in 1767 , he had married a Greek woman at a time when the Greek bishop was disputing such marriages. At the time, de Hochepied considered van Brakel as careless, because he had celebrated his marriage in public. ${ }^{134}$ After van Brakel's behaviour at the trial with Alexander \& Sottira, de Hochepied called him a 'stubborn creature', and he wrote to the States General that he wanted to expel van Brakel from the Dutch community to set an example. ${ }^{135}$ When this was communicated to the Directorate of Levant Trade, its directors concurred, even though it was an unusual decision. Van Brakel lost his Dutch-protected status but would later return to the fold. He even became chancellor of the Dutch consulate between 1783 and 1804 and then treasurer until his death in $1817^{136}$

This case is remarkable for a number of reasons. Although Alexander \& Sottira were Ottoman subjects, they accepted the principle of forum rei and initially took the case to the Dutch consular court, most likely because they felt their case was strong and the existence of Dutch exchange law would be in their favour. It does indicate that certain traders had the option of forum shopping and took it. Van Brakel was not the only European merchant to complain about Ottomans seeking the best of both worlds. On several occasions, Europeans complained of the legal actions undertaken by several Ottomans who could choose either a European or an Ottoman court for litigation. ${ }^{137}$ This choice was formally also open to European traders, as by the middle of the eighteenth

\footnotetext{
132 NACS, $\mathrm{N}^{\circ} 343$, 'Sententie in de differentie van Alex:r \& Sottira \& $\mathrm{C}^{\circ} \mathrm{x}$ g: van Brakel', Izmir, O2/09/1769.

133 NACs, $\mathrm{N}^{\circ} 343$, 'Annotatie van appel van Alex:r en Sottira teegens van Brakel', Izmir, o4/o9/ 1769 .

134 Something he expressed in a letter sent on $01 / 08 / 1767$, mentioned in a footnote in Heeringa and Nanninga, Bronnen tot de geschiedenis, 4: p. 192.

135 The quote comes from a letter written by Consul de Hochepied to the States General, Izmir, 03/07/1769, mentioned in a footnote in Heeringa and Nanninga, Bronnen tot de geschiedenis, 4: p. 192, '[...] soo een koppig schepzel [...]'.

136 See footnote 162 on p. 237 .

137 See pp. 308-312.
} 
century all European capitulations contained options for Europeans to choose litigation at an Ottoman court. The fact that Europeans did not appear eager to do so does not take anything away from their option to do so. ${ }^{138}$ The case of Alexander \& Sottira proves that Ottomans did not even need to be a European protégé. By remaining silent vis-à-vis Ottoman authorities and simply accepting Dutch competence, a nonprotected Ottoman could be tried at a European court in cases where he wanted to prosecute a European as plaintiff. Protégés had the same option, but it was expanded, with the right to seek legal recourse as defendant due to their protected status, an option several of them took.

\subsection{Ottoman Justice and European Protection}

In 1766, an Ottoman Armenian trader in Amsterdam named Alexander di Massé started having difficulties paying bills of exchange drawn on him by the firm of Massé, di Herabeth \& Sons in Izmir, in which one of the partners was Isaie di Massé, Alexander's brother. The inability of Alexander to pay for the bills issued by Massé, di Herabeth \& Sons created a huge problem for Isaie di Massé in Izmir. ${ }^{139}$ In May 1768 Consul Daniel Jean de Hochepied wrote to the States General about the return of unpaid bills of exchange drawn by Massé, di Herabeth \& Sons on Alexander di Massé. Isaie di Massé was a Dutch protégé (see table 3), which is why seven merchants holding his bills turned to the consul to demand payment from him. The consul gave di Massé twentyfour hours, 'according to usage in those cases', or the option to find a surety for the amount he owed. ${ }^{40}$ Di Massé replied he was unable to pay, as too many protested bills had returned from different places at once. He needed time, but the merchants were adamant and demanded that the consul seal di Massé's effects and order his business books to be handed over. The consul replied that he could not do this, because di Massé was an Ottoman subject, and even though he was also a Dutch protégé, the consul stated he 'could not

${ }_{13} 8$ It has been argued, for Ottoman courts in seventeenth-century Istanbul, that a bias existed against non-Muslim litigants, which might explain the lack of European enthusiasm to appear before an Ottoman judge; on this see Timur Kuran and Scott Lustig, 'Judicial biases in Ottoman Istanbul. Islamic justice and its compatibility with modern economic life', Journal of law and economics, 55 (2012): pp. 1-48.

139 For Alexander di Massé and the financial problems created by the bills, see Ismail Hakkı Kadı, 'On the edges of an Ottoman world: Non-Muslim Ottoman merchants in Amsterdam', in The Ottoman world, ed. Christine Woodhead (London and New York, 2012), pp. 276-288; see also Hakkı Kadı, Ottoman and Dutch merchants, pp. 215-223.

140 Heeringa and Nanninga, Bronnen tot de geschiedenis, 4: pp. 99-100, Consul Daniel Jean de Hochepied to the States General, Izmir, 18/05/1768, on p. 99, '[...] volgens gebruyk in dusdaenige gevallen $[\ldots]$ '. 
act completely according to the laws of our lands - in order to avoid the avanias that might result from this.'141

This is an important remark for understanding the dual position of the Ottoman protégés. They had obtained certain privileges, similar to those granted to the European trading communities, including the right to be tried as defendant before a European court, but at the same time, they also remained Ottoman subjects. This could offer them protection from European action. It might have been formally possible for the consul to follow European legal practice and seal di Massé's effects, but he feared that it might lead to the involvement of Ottoman officials who would counteract such a decision to protect Ottoman interests. ${ }^{142}$ These interests were not only with the person of Isaie di Massé. After denying the request of the European merchants, de Hochepied decided to receive all of di Massé's creditors in his house. There were fifty-four in total, forty-seven Ottomans, which included 'Turks, Jews, Greeks and Armenians', and 'seven Frankish firms.' ${ }^{43}$ The Ottomans took a united stance by allowing di Massé the fifteen-day period he had asked for to come up with a payment plan. The Ottomans expected the Europeans to agree but stated that if they did not, they would file an official protest against the Europeans at an Ottoman court and hold them responsible in case the firm of Massé, di Herabeth \& Sons went bankrupt. De Hochepied continued by stating that the Europeans were forced to give in, considering there was a majority of forty-seven against seven. When the Europeans asked Isaie, who was also present at the meeting, how much he owed, the Ottomans protested, claiming di Massé should be left alone. The consul concluded by writing that di Massé had showed a great deal of courage and hoped he would be able to pay and save himself. ${ }^{144}$

The Ottoman majority amongst the creditors must have worried the consul, as it brought the risk of litigation before an Ottoman qadi court. Europeans generally hoped to avoid this. When Pieter Ouckama entered into financial difficulties in 1769 that led to his bankruptcy, for instance, the consul explained

\footnotetext{
141 Ibid., '[...] konde ik niet volkoomen ageeren volgens de wetten onser landen - om de avanies, die er mogten opkoomen, te eviteeren [...]'.

142 The capitulations do not contain much on the involvement of Ottoman courts in bankruptcy cases, but they did include stipulations protecting European traders and protégés from 'unexpected financial demands as a result of debts incurred by others'. Van den Boogert, The capitulations, pp. 212-213.

143 Heeringa and Nanninga, Bronnen tot de geschiedenis, 4: pp. 99-10o, Consul Daniel Jean de Hochepied to the States General, Izmir, 18/o5/1768, '[...] Turken, Jooden, Grieken, en Armeenders [...] seeven Frankse huysen [...]'.

144 Ibid.
} 
to Hendrik Fagel, then working at the States General, that Ouckama was lucky he did not have any 'Turkish' (i.e., Muslim) creditors, only Jews, Greeks and Armenians. They all came to visit the consul to find a solution but 'did not have the heart' to seek recourse at an Ottoman court. ${ }^{145}$ De Hochepied seemed to have been too optimistic, because Ouckama fled from Izmir not much later, claiming his creditors had threatened to have him arrested by the 'Turks' and bring him in chains to Istanbul, in spite of an earlier agreement allowing him to travel to Holland to procure funds. ${ }^{146}$

In the case of Massé, di Herabeth \& Sons, it is clear that the Ottoman creditors were in the majority and were also aware that, although they accepted to negotiate an outcome at the Dutch consul's house, they used the option of Ottoman justice as means of pressuring the Europeans into following their solution, which was to extend time to di Massé. The granted time period of fifteen days ran from 6 to 15 June, and when it ran out, the Dutch chargé d'affaires in Istanbul, Frederik Johan Robert de Weiler, wrote to the Directorate of Levant Trade that Massé, di Herabeth \& Sons had declared bankruptcy, which immediately caused a great deal of trouble in Istanbul and Izmir. Several goods ready to be shipped by the bankrupt firm from Izmir to the United Provinces had been sequestered by the Ottoman authorities. De Weiler was trying to liberate the goods by obtaining a ferman from the Porte, but he feared that the 'Turkish' and Ottoman subjects would not lose so much in the bankruptcy, contrary to the Europeans. ${ }^{147}$

Not much later, the consul arrested Isaie di Massé, and while the latter was still in custody, some of the 'Turkish' creditors informed de Hochepied that they had agreed with the firm to get paid $25 \%$ of their debts within six months and that subsequently, di Massé should be released. The consul refused on the grounds that he had not only been arrested on demand of the qadi but also at the request of three French firms. This angered the 'Turkish' creditors, who gathered with a group of forty and a number of men of the Ottoman justice and appeared before the consul's house to threaten him and demand di Massé's liberty. The consul replied that 'our laws' impeded this, and he could not agree unless the French firms consented. ${ }^{148}$ The group then moved to the

145 Heeringa and Nanninga, Bronnen tot de geschiedenis, 4: pp. 127-129, Consul Daniel Jean de Hochepied to Fagel, Izmir, $17 / 03 / 1769$, on p. 128, '[...] hadden zij 't hart niet [...]'.

146 See the documents in NACS, $\mathrm{N}^{\circ} 254$ ('Stukken betreffende faillissementen. Pieter Ouckama, Nederlands koopman te Smyrna, 1769').

147 Heeringa and Nanninga, Bronnen tot de geschiedenis, 4: p. 103, Chargé d'affaires Frederik Johan Robert de Weiler to the Directorate of Levant Trade, Istanbul, 15/06/1768.

148 Heeringa and Nanninga Bronnen tot de geschiedenis, 4: pp. 108-109, Consul Daniel Jean de Hochepied to Fagel, Izmir, $18 / 07 / 1768$, '[...] onse wetten [...]'. 
house of the French consul, who wanted some time to consider, so everyone returned to the Dutch consul's house, who then agreed to liberate di Massé on the double condition that two Armenians stood as surety for him and that he would not run away. ${ }^{149}$

The news had already spread to the United Provinces, and in June 1768, the firm of Thomas de Vogel \& Zoon wrote to David van Lennep in Izmir that they were not surprised about the bankruptcy, as they felt the firm had been poorly run. They heard the 'Turks' had taken possession of everything, with nothing left for the Christians. They feared Alexander di Massé in Amsterdam would suffer the same fate, and it seems that he indeed went bankrupt too, but managed to repay most of his debts, meaning his reputation remained intact. De Vogel was sorry for Alexander di Massé, who he felt he was a good man. ${ }^{150}$

The Directorate of Levant Trade used the example of Massé, di Herabeth \& Sons to warn Dutch traders to think twice before entering into business with Ottoman firms, suggesting that any advantage that derived from it would be 'twice destroyed by unforeseen damages later'. ${ }^{151}$ Two days later, the Directorate of Levant Trade expressed disappointment that the 'Turkish' creditors had taken everything from the bankrupt firm, even several goods that belonged to Dutch traders, which had been consigned to Massé, di Herabeth \& Sons. ${ }^{152}$ It is difficult to verify if European complaints about arrangements that turned out well for Ottomans were justified in each individual case, but Maurits van den Boogert has demonstrated that many negative European comments on Ottoman practice were evidence of a particular European way of thinking and did not point to the existence of an unjust Ottoman legal system. He demonstrated that settlements that were unfair in European eyes were 'a pragmatic method of dispute resolution between Ottomans and Europeans that was more common in this period than many Europeans cared to admit.'.153

Two years later, the firm of Massé, di Herabeth \& Sons found itself in another predicament in spite of the good standing the di Massé brothers enjoyed. Alexander's business in Amsterdam had picked up again, and Isaie

\footnotetext{
149 Ibid.

150 Ibid., pp. 1239, Thomas de Vogel to David van Lennep, Amsterdam, 21/06/1768. It seems that Alexander di Massé fully recovered. When he died in 1803, he left a considerable estate. Hakkı Kadl, 'On the edges of an Ottoman world', p. 282.

151 Heeringa and Nanninga, Bronnen tot de geschiedenis, 4: pp. 112-113, Directorate of Levant Trade to consul, treasurer and assessors in Izmir, Amsterdam, 20/o9/1768, on p. 113, '[...] naderhand door onversiene schaadens dubbeld werden vernietigt [...]'.

$15^{2}$ Ibid., pp. 113-115, Directorate of Levant Trade to the States General, Amsterdam, 22/og/ 1768.

153 Van den Boogert, The capitulations, p. 157.
} 
stood in good contact with the Dutch ambassador in Istanbul, to whom he sent several gifts. ${ }^{154}$ The problem was that, in an effort to counter the effect of their bankruptcy, the Armenian firm had summoned one of their debtors, Caspar di Carabeth, before Ottoman justice. On 25 November 1770, Caspar and Simon di Carabeth made a request to the Dutch consul to take away all Dutch assistance to Isaie di Massé in his dealings with Ottoman justice, as well as his protected status. They felt di Massé had made 'vain pretentions and unjust demands' and that he had every opportunity to bring the dispute before the Dutch consul. ${ }^{155}$ They found his actions to be particularly inexplicable considering he was a debtor to Simon di Carabeth himself. So, as Caspar di Carabeth was brought before Ottoman justice, they felt that di Massé should also be brought before Ottoman justice, as a raya, and with 'the greatest respect' they asked the consul to remove the protected status from di Massé. ${ }^{156}$

The Dutch ignored this request, as they were fully sympathetic to the cause of di Massé. A remark added by chancellor Mann underneath the request shows that the Dutch were keen on avoiding Ottoman justice altogether. Mann, who was still hoping to bring the case before arbitrators, had asked di Massé to contact Ottoman justice in an effort to obtain the release of Caspar di Carabeth, who had been arrested, but di Massé refused. ${ }^{157}$ Di Massé must have felt strongly about his chances at Ottoman justice, but Consul de Hochepied expressed 'his great surprise', as he could not understand how Isaie di Massé, principal partner in the firm and Dutch protégé, could bring anyone before an Ottoman court without first consulting him or the first dragoman of the Dutch consulate

154 The ambassador felt obliged to accept some fish and fifty watermelons, and to return fiftytwo bottles of red wine, as his general feeling was that he could only accept gifts of limited value. He had to assure di Massé that this was not because he held di Massé in low esteem. Heeringa and Nanninga, Bronnen tot de geschiedenis, 4: p. 13, Ambassador Willem Dedel to Isaie di Massé, Istanbul, 11/10/1765.

155 NACs, $\mathrm{N}^{\circ} 347$ ('Massé di Carabeth, Armeens koopman te Smyrna, tegen zijn broer Caspar di Carabeth, 1770'), 'Request van Caspar \& Simon di Carabeth om aen Masse de assistentie \& protectie te onttrekken', Izmir, $25 / 11 / 1770$, ' [...] vane pretenzionij e ingiuste dimande [...]'. The reference to this case in the catalogue of the Dutch national archives mistakenly identifies the litigants in this case as Massé di Carabeth and Caspar di Carabeth, two brothers. It was a case between the firm of Massé, di Herabeth \& Sons and Caspar di Carabeth. While the documents also mention a Simon di Carabeth, his exact relationship to Caspar is unclear; but at least the two were not opposing parties. To further complicate matters, the firm of Massé, di Herabeth \& Sons remains mysterious in terms of partners. Hakkı Kadı consistently refers to it as Massé, di Carabeth \& Sons. See for instance Hakkı Kadı, Ottoman and Dutch merchants, p. 218.

156 NACs, $\mathrm{N}^{\circ} 347$, 'Request van Caspar \& Simon di Carabeth om aen Masse de assistentie \& protectie te onttrekken', Izmir, 25/11/1770, '[...] con il maggior rispetto [...]'.

157 Ibid. 
in Izmir, a Greek named Diodato Abro. ${ }^{158}$ De Hochepied's surprise was not as remarkable as it seems, because it was granted in the Dutch capitulations that Dutch litigants, which di Massé was due to his berat, could be assisted by a dragoman of the Dutch nation as his interpreter before an Ottoman court. ${ }^{159}$ Perhaps di Massé thought that, as an Ottoman subject, he did not need such assistance, but de Hochepied expressed the fear of creating a precedent which could lead to a general practice of litigation before an Ottoman court involving Dutch protégés without the assistance of dragomans. ${ }^{160}$

Part of di Carabeth's goods had been sequestered by the Ottomans, which was not to de Hochepied's liking, and he wanted his chancellor to speak to Abro so a way could be found to lift the sequester. De Hochepied felt the dispute should either be examined by himself or by 'good men', referring to the possibility of settling through arbitration. ${ }^{161}$ In a way, it was a remarkable choice. Di Carabeth had no connection to the Dutch community through a berat, and di Massé could at least claim some debts, which in turn might be used to pay off European creditors who had not found satisfaction in the resolution of the bankruptcy two years earlier. It seems likely that the consul was motivated by a desire to preserve the autonomy of legal procedures as granted to him in the capitulations, and litigation before an Ottoman court posed a threat to that autonomy, at least in the consul's eyes.

After the consul's letter to Chancellor Mann, a meeting was organised between Isaie di Massé and five other Armenians, Babi di Arun, Aretun di Minas, Lucas di Marcos and Malcas and Simon di Carabeth. These last two were relatives of Caspar di Carabeth, and Malcas was not unknown to the Dutch consul, as he was the Armenian trader with whom the Dutch merchant Isaac Beaune had hoped to establish a intercultural partnership in Izmir before the consul forbade him to do so. ${ }^{162}$ In the meeting, an agreement was reached to put the dispute before four arbitrators, each party choosing two, and an eventual fifth should their opinions be divided. Their judgment should be accepted without the possibility of appeal. It was also agreed that Isaie di Massé should pay for the expenses related to the Ottoman sequester and its lifting, as well as for the

158 NACs, $\mathrm{N}^{\circ} 347$, Consul Daniel Jean de Hochepied to chancellor Johan Frederik Mann, Izmir, 25/11/1770, '[...] tot mijne groote verwondering [...]'. For the appointment of Abro as dragoman between 1765 and 1797 , see Schutte, Repertorium der Nederlandse vertegenwoordigers, p. 345 .

159 See pp. 84-85.

160 NACs, $\mathrm{N}^{\circ} 347$, Consul Daniel Jean de Hochepied to chancellor Johan Frederik Mann, Izmir, 25/11/1170.

161 Ibid., '[...] goede mannen [...]'.

162 See p. 288. 
release of Caspar, who was held by the Ottoman authorities. Di Massé's actions should be considered an 'avania caused by him', but since he had no funds, the four other Armenians were to advance it, and it would be subtracted from di Carabeth's debts. ${ }^{163}$ If di Carabeth was not found to be indebted to di Massé, the latter had to pay for all expenses. As surety, di Massé was asked to deposit the actual document of the berat he had bought and that had given him Dutch protection. ${ }^{164}$ The four other Armenians stood as surety for di Carabeth. ${ }^{165}$

On 29 November 1770, Chancellor Mann, who had been present at the meeting, informed the consul about the events that had occurred. He reported about the compromise to send the case to arbitration but added that several of the Armenians had changed their minds, declaring that they were rayas who had nothing to do with Dutch justice. ${ }^{166}$ Mann had apparently confronted the Armenians directly, asking them why they had sent a request to the Dutch consulate if they did not want to have anything to do with its justice. They ignored the question, not knowing that Mann had the actual request in his pocket. ${ }^{167}$ They claimed to only have come out of friendship, but Mann concluded that their attitude made it clear that they did not want to be judged. The chancellor was convinced that they would be unwilling to pay anything if the arbitrators concluded that di Carabeth owed money to di Massé. The chancellor continued his report by stating that, after they had spoken to him, the Armenians had physically assaulted di Massé, after which he had agreed to subtract all expenses made from the debt. He also agreed to help to secure the release of Caspar. ${ }^{168}$

It is not clear how the case was resolved, but the Dutch authorities fully stood behind Isaie di Massé. The consul felt that he and di Massé had justice at their side and demanded that Caspar provide the surety asked from him, sign the compromise and accept arbitration or fully declare himself a raya and accept the consequences, which would be a continuation of the case before Ottoman justice. Should this happen, the consul instructed Mann to talk to Diodato Abro, who had to go to di Massé, because 'I absolutely want di Massé

\footnotetext{
163 NACs, $\mathrm{N}^{\circ} 347$, undated and unsigned declaration, '[...] avania da lui causato [...]'.

164 Berats were commodities that could be bought and sold; see pp. 61-64.

165 NACS, $\mathrm{N}^{\circ} 347$, undated and unsigned declaration.

166 NACs, $\mathrm{N}^{\circ} 347$, Chancellor Johan Frederik Mann to Consul Daniel Jean de Hochepied, Izmir, 29/11/1770.

167 Some, or all, of the four Armenians must thus have brought the case before the Dutch consulate, which was not strange considering two of them were di Carabeth's relatives, but the actual request has not been preserved.

168 NACs, $\mathrm{N}^{\circ} 347$, Chancellor Johan Frederik Mann to Consul Daniel Jean de Hochepied, Izmir, 29/11/1770.
} 
to be assisted.169 Di Massé was a well-respected protégé; his earlier bankruptcy had led some Dutch merchants to sympathise with him, expressing their hopes that he would recover. ${ }^{170}$

The consul's remark about Caspar di Carabeth having to declare his status as raya suggests that the man had some choices to make. No evidence was found, and no mention was made, however, of any privileged status for di Carabeth. The choice to turn to arbitration was not strange, as the peaceful resolution of conflict was often attempted before litigation, but it seems peculiar that di Massé addressed Ottoman justice then refused to withdraw his request when the consul asked, only to then agree to arbitration. The consul and Armenian friends of di Carabeth must have pressured him. It is not clear how the case was resolved, but in 1784 , Caspar di Carabeth travelled to Amsterdam to visit Alexander di Massé, demonstrating that he had an interest in Dutch Levant trade (which might have created the initial quarrel on the debt). ${ }^{171}$ Di Carabeth might have been trading with the United Provinces on his own account, through di Massé, which would be an additional reason to seek peaceful resolution through the consulate.

As the assistance provided to di Massé, in spite of his earlier bankruptcy and his choice of turning to Ottoman justice, shows, the Dutch took their protection duties seriously. The status of the protégés provided them with certain privileges, and rather than seeking recourse at Ottoman courts, they did resort to consular justice when they felt that these privileges were harmed or threatened. In 1782, for instance, a Chiot trader named Jani Mavrogordatos complained to the Dutch consul that he was subjected to taxes and custom duties by Chios magistrates, while as a protégé he was exempt from them. Clearly, traders used their expensively bought protégé status as means to gain commercial profit, and when that did not work out because of the different administrative legal and administrative systems, they sought what was to their best advantage. These developments furthered the opportunities for forum shopping mentioned earlier, in this case allowing a Greek Ottoman subject to turn to Dutch diplomacy trying to avoid paying tariffs. ${ }^{172}$

169 NACs, $\mathrm{N}^{\circ} 347$, Consul Daniel Jean de Hochepied to Chancellor Johan Frederik Mann, Izmir, '[...] ik wil apsolut hebben dat men masse assisteert [...]'. The note is undated and only mentions that it was written on a Thursday afternoon.

170 See p. 301.

171 Hakkı Kadı, 'On the edges of an Ottoman world', p. 282.

172 NALT, $\mathrm{N}^{\circ} 626$ ('Memoire par les affaires des barataires de Scio'), 'Mémoire présenté a la Porte', S.l., $17 / 12 / 1782$. 


\subsection{European Fear of Ottoman Abuses}

In 176o, Consul Daniel Jean de Hochepied wrote to the States General about the case of Yaqub Çelik, an Armenian merchant based in Izmir who had gone bankrupt. De Hochepied had received directives from the States General to assist the merchant firm of van Lennep \& Enslie, who carried a power of attorney from the creditors of Çelik's son Serkis, based in Amsterdam. Van Lennep \& Enslie had been instructed to claim some of Yaqub's goods that had been sequestered by the consul. Yaqub Çelik, it was specified, was an Ottoman subject who enjoyed Dutch protection through the purchase of a berat with help from the Dutch ambassador in Istanbul and which had been accepted by the Porte. While reflecting on Çelik's case, Consul de Hochepied condemned the practice of forum shopping:

those people of the land [Ottoman Empire] serve themselves effectively from the berats and protections of the Europeans, for as long as it coincides with their interest, and as soon as they observe, particularly in bankruptcies, that those berats do not coincide with their own particular interests, they abandon berats and protections, and return to Turkish protection, in which case no ambassador or consul has the power to interfere, unless with the risk of opening the whole nation to unbelievable and unthinkable inconveniencies, avanias and liability. ${ }^{173}$

The consul then wrote to the ambassador in the hope that the Porte would acknowledge the need for Çelik's Ottoman creditors to fully understand the rights of the creditors in the United Provinces and thus accept a settlement that included them all. The ambassador replied that such a thing would only be possible if Yaqub Çelik would declare, at the instigation of all his creditors, in an Ottoman court that his bankruptcy was not fraudulent and that he had

173 Heeringa and Nanninga, Bronnen tot de geschiedenis, 3: pp. 402-404, Consul Daniel Jean de Hochepied to the States General, Izmir, 15/o9/176o, on pp. 402-403, '[...] welke menschen van 't land sig effective maer soo lang van de baratten en protextiën der Europeëren bedienen, als het haar met derselver belangen conveniëert, en soo ras sy bespeuren, insonderhijd by faillissementen, dat die baratten met haere bysondere belangen niet overeenkoomen, soo laeten sy baratten en protextiën vaeren en begeeven haer weederom onder de Turkse protextiën, wanneer dan geen ambassadeur off consul meer de magt heefft sig het allerminste meer met haer te bemoeyen, tenzy sig en de gansche natie in de gevolgen aen ongeloofelyke en onbedenklyke inconveniëntiën, havaniën en verantworrdinge bloot te stellen $[\ldots]$ '. 
no other possessions than the goods that were already sealed off by the Dutch. According to de Hochepied, this was not possible, because it had become clear that Yaqub's Ottoman creditors did not agree with those of Serkis Çelik in the United Provinces. The Ottoman creditors, who were positioning themselves as the competitors of the Dutch creditors, expressed no interest in prosecuting Yaqub Çelik, expecting to obtain more money from him by waiting.

In the meantime, a third party had entered the stage, the Ottoman proprietors of the khan in which Yaqub Çelik's warehouse was located. As was normal in bankruptcy procedures, Çelik's warehouse had been sealed off by the Dutch authorities, awaiting inventory and possibly a public sale to cover his debts. The khan proprietors were claiming unpaid rent from the Armenian and threatened to get it by petitioning the local Ottoman court to break the seal so they could take goods as compensation. De Hochepied argued that this was not only disadvantageous to the Dutch creditors, it also went against the legal autonomy stipulated in the capitulations, which also held in the case of a bankruptcy procedure. In a meeting amongst Dutch merchants in Izmir, it was decided to hold off the Ottoman creditors for the time being. The khan proprietors protested, and afraid of the possible repercussions, the consul wanted van Lennep \& Enslie to pay the rent or cancel the sequester. ${ }^{174}$

This example clearly shows that European jurisdiction was challenged by Ottoman traders and that Europeans were afraid of the consequences such challenges could bring. On the one hand, the capitulations ensured European legal autonomy, which also applied to Yaqub Çelik as a Dutch protégé. On the other hand, the bankruptcy involved Ottoman creditors in the Ottoman Empire. While attempting to safeguard the interests of Dutch creditors, as specifically demanded by the States General, de Hochepied also knew that the Dutch lived as 'guests' of the sultan and that, while trying to point to the capitulations to keep a maximum of legal agency, they had to accept that there were limits, and these limits were not set according to a Dutch logic, but to an Ottoman one. There was always a risk in objecting too much to an Ottoman resolution to a particular dispute, and it could be harmful to the Dutch trading nation as a whole.

Forum shopping in Izmir was different for Ottomans and Europeans. Europeans had agreed on the unwritten rule of forum rei, an existing principle stipulating that the jurisdiction of the defendant would be chosen for adjudication. Europeans were allowed, through the capitulations, to choose to appear before an Ottoman court, as long as both litigating parties agreed.

174 Ibid. 
While evidence shows that European diplomats discouraged their subjects from litigation before an Ottoman court, the use European merchants made of Ottoman courts, such as the qadi, has not been analysed. ${ }^{175}$ Before the appearance of European traders in Ottoman courts is better understood, no assertion can be made about the advantages Ottomans had over Europeans. But the latter often felt that the protégés, because of their dual legal identity as Ottomans and Europeans, had an unfair advantage over them. This also included the assumption that Ottoman Jewish or Christian protégés who had bought European protection through a ferman were, unlike the Europeans themselves or members of their communities without ferman, free of avanias: 'fermans or orders, which liberate them of all avanias brought upon their nations.'176

These perceived competitive advantages of the protégés led to frequent requests from Dutch traders to their diplomatic representatives, in which they demanded that protégés would be forced to choose their legal status, either European or Ottoman - although such a choice was not possible. ${ }^{177}$ Added to this was the fear that the appearance of a Dutch Ottoman protégé before an Ottoman court rendered the Dutch community as a whole vulnerable to avanias. While there are no indications that such a thing happened, Dutch diplomats feared that Ottoman adjudication involving their protégés could lead to a situation in which Ottoman justice would attempt to exercise jurisdiction over all Dutch merchants based on the situation created by the protégé. ${ }^{178}$

The fear fitted within the general European concern that the Ottoman authorities would violate the privileges specified in the capitulations, which Europeans considered as sacrosanct. ${ }^{179}$ This fear meant that, in their assessment of interactions with Ottoman officials, European diplomats often expressed themselves in very strong terms in their correspondence, labelling Ottoman actions as unfair, unjust or unpredictable. The problem for Europeans was perhaps the feeling that, no matter how they interpreted the capitulations, they were still living under an Ottoman administration that could alter the terms of the relationship when they wanted. As such, use of the pejorative

\footnotetext{
175 Van den Boogert, The capitulations, p. 44.

176 Heeringa and Nanninga, Bronnen tot de geschiedenis, 3: pp. 357-358, Van Asten to Elbert de Hochepied, Aleppo, o9/o2/1757, on p. 357, ‘[...] firmans of commandementen, die haarlieden bevryd van alle avanies, die op haare natsies gebragt werden [...]'.

177 See also pp. 61-64 and $277^{-281}$.

178 Heeringa and Nanninga, Bronnen tot de geschiedenis, 3: pp. 27-29, Ambassador Cornelis Calkoen to Fagel, Istanbul, o8/11/173o.

179 Van den Boogert, The capitulations, p. 21.
} 
term avania was nothing more but the expression of European vulnerability. This was further fuelled by the understanding that a whole trading community could be made to pay the consequences of an individual action.

European diplomats were well aware of this vulnerability, particularly when dealing with Ottoman merchants, and the Dutch consul in Izmir warned his merchants to be conscious of their actions, fearing the creation of a precedent in which the whole Dutch community would be held accountable for individual missteps. When Pieter Ouckama declared bankruptcy in 1769 , the Dutch consul suggested a public sale of Ouckama's furniture in order to raise money to pay off as much debt as possible. Local creditors had refused, as they wanted Ouckama's furniture stored in a warehouse until the bankrupt's future intentions were clear. Daniel Jean de Hochepied remarked that he did not need to listen to the desires of the creditors, as he was 'authorised by our laws as magistrate of our nation here' to proceed with the public sale, but he would nevertheless respect the wishes of the local creditors in order to 'not be exposed to any avania that they could bring on us or on our nation.' 180

Just like the embeddedness of collective punishment in European medieval legal context, the principle that a whole community of foreigners (in this case a European trading community in the Ottoman Empire) could be held accountable by the host society for the individual behaviour of one of its members is fully in line with Ottoman legal tradition. ${ }^{181}$ According to Işık Tamdoğan, who analysed a sodomy trial brought before the qadi court of Adana, 'the evolution of the notion of collective responsibility in Ottoman jurisprudence has a long history'.182 According to Tamdoğan, Ottoman use of forms of collective responsibility not only applied in both Islamic and kanun law but also found their way into eighteenth-century taxation systems. ${ }^{183}$ The understanding that there was an old legal tradition, both in Europe and the Ottoman Empire, of collective responsibility - one that did not exclude individual accountability - provides

180 NACs, $\mathrm{N}^{\circ} 254$, 'Order van de heeren consul thes $\mathrm{x}$ assessooren tot het bergen der boedel van Ouckama \& $\mathrm{C}^{\circ}$ tot nader dispositie in een brandvrij magazijn', Izmir, 24/05/1769, '[...] schoon door onse wetten daer toe g'authoriseert als magistraat der Nederlandse natie alhier]' and '[...] niet bloot te stellen, aen deese of gene avania, die sij aen ons off onse natie soude konnen maaken [...]'.

181 For European legal embeddedness, see Ogilvie, Institutions and European trade, pp. $272-276$.

182 Işık Tamdoğan, 'The Ottoman political community in the process of justice making in the 18th-century Adana', in Forms and institutions of justice. Legal actions in Ottoman contexts, eds. Yavuz Aykan and Işık Tamdoğan (Istanbul, 2018), consulted online at https:// books.openedition.org/ifeagd/2323.

183 Ibid. 
an additional argument for the idea that European views on Ottoman corruption and extortion were false.

A good example is the Ottoman reaction to the growing involvement of Ottoman Greeks in Dutch Levant trade in the 176os. To avoid paying higher customs duties, some of these Greeks covered their transactions by borrowing the name of Dutch traders, with their consent. ${ }^{184}$ When Ottoman officials discovered this practice, they threatened to hold the whole Dutch community responsible, not just the merchant who had lent out his name. ${ }^{185}$ It seems that in certain potential disputes, measures had been taken to avoid the unwished use of collective responsibility mechanisms. Article 28 of the 1612 Dutch capitulations specified that 'if a Dutchman becomes a debtor, the debt must be demanded from the one who owes it and no other may be arrested or required to pay unless he has stood as surety'.186 The inclusion of such an article suggests that an opposite practice could be imagined. Indeed, in 1767 , the Dutch ambassador in Istanbul wrote to the States General to obtain advice about potential Ottoman infractions against the capitulations. One of the examples he used was the practice in which powerful Ottomans purchased certain debts that were owed by Dutchmen and intended to hold the ambassador or the whole Dutch trading community responsible for them. ${ }^{187}$

\subsection{Greek Community Resolutions}

The mechanism of collective responsibility was not the only option available within the Ottoman legal context to avoid or punish the cheating behaviour of traders without immediately going to court. The Ottoman legal system also allowed for forms of friendly community settlements in much the same way as certain European societies did. The obvious example is the legal autonomy granted to European consuls through the capitulations, but Ottomans allowed for intracommunity resolutions for their millets as well. On occasion, documents related to such processes found their way to European chanceries in the Levant, because Ottoman traders with a berat were able to challenge community resolutions by resorting to consular adjudication. An example is the resolution of the dispute between two Greek traders, both holders of a European berat. In 176o, French protégé Manolaki di Panaiotis was taken to court by a

\footnotetext{
184 See pp. 248 and $284-285$.

185 Heeringa and Nanninga, Bronnen tot de geschiedenis, 4: p. vi.

186 Quoted from de Groot, The Ottoman Empire, p. 153.

187 Heeringa and Nanninga, Bronnen tot de geschiedenis, 4: pp. 73-77. Ambassador Willem Dedel to Fagel, Istanbul, 15/og/1767.
} 
fellow Greek trader, Panaiotis Pittaco, who was a protégé of the Dutch consulate, for unpaid debts. 188

Initially, the case was subject to judgment within the Greek community by the Greek bishop and three merchants, who sentenced di Panaiotis to pay his debts. When the French protégé stalled his payments for too long, Pittaco went to court. Because di Panaiotis was a French protégé, the case had to be tried by the French consul. Some documents pertaining to this case have been preserved in the archives of the Dutch consulate because Pittaco, as a Dutch protégé, was allowed to deposit his documents at the chancery of the consulate under whose jurisdiction he fell. The Dutch chancellor brought copies of the documents to his French colleague and vice versa. In this case, the French chancery withheld several documents, because the title on the trial documents explicitly mentions that paperwork was in the French chancery and had not been shown to the Dutch consulate, which was not the normal procedure. ${ }^{189}$

The case's first document kept in the Dutch chancery is a declaration in Italian, made by Pittaco on behalf of the Dutch consul and signed by the Greek bishop and the three Greek merchants involved in the original sentencing, Leone Prasacachi, Demetrio Vitale and Giovanni Zingrilara. ${ }^{190}$ The dispute and the original sentencing was explained, as well as the recourse sought at the French consulate. A day after it had been drafted, Dutch chancellor Haan added a paragraph declaring he had gone to see the bishop and the three merchants in the presence of two witnesses - Gualtiero Gallo and Luca Homero, both well acquainted with the Dutch community in Izmir. ${ }^{191}$ This personal visit confirmed the situation, and de Hochepied ordered that both the Greek declaration and Haan's addition should be copied and sent to the French chancery so di Panaiotis could read it and reply.

The problem was that a man named Ağa Esse was indebted to Pittaco for a sum of 2,500 lion dollars. The first 1,500 lion dollars came from an older debt that remained unspecified, but the second came from a loan given by Pittaco after mediation with Manolaki di Panaiotis, who had insisted for Pittaco to grant Esse the loan and who was willing to stand as surety. When

188 This was the same di Panaiotis who was later involved in the case between Dirk Knipping and Jacques Forêt and who also had a dispute with Jacob de Vogel. The papers of the case can be found in NACS, $\mathrm{N}^{\circ} 324$ ('Papieren der proces van Manolachi de Panajottis X Panajotti Pittaco, welke door den Grieksen bischop zijn uijtgesprooken \& de sententie in de Franse cancellerij berust, sonder ter deeser cancellerij te zijn vertoond, 1761').

189 Ibid.

190 The choice of these three merchants might not be a coincidence, as at least two of them, Vitale and Zingrilara, had been or still were under Dutch protection at the time.

191 Gallo was working for the Directorate of Levant Trade in 1766. See table 1. 
di Panaiotis promised that he would pay Pittaco the 1,00o lion dollars back within a year, should Ağa Esse not be able to, Pittaco was convinced, as he immediately accepted these terms. ${ }^{192}$ Unfortunately, Ağa Esse went bankrupt, and his creditors agreed to try to recuperate $70 \%$ of Esse's debts. Pittaco did not want to side with that claim, in the hopes to fully reclaim his money. Di Panaiotis seemed to agree and convinced him to remain patient and not go to court. No agreement was reached, and eventually, Ağa Esse's son turned to the Greek bishop in Izmir for help, who summoned Pittaco before him in person. In the meantime, a man from Ankara named Ağa Raz promised to pay off part of the debt to Pittaco, but nothing happened, so the case was put before the Greek bishop and three Greek merchants, who decided that Manolaki di Panaiotis, as surety, was liable. He promised to pay the 1,0oo in cash, and the remaining 1,500 would be satisfied by a delivery of cochineal at twenty lion dollars per ocque. ${ }^{193}$ Pittaco was willing to forget the interest of 116 lion dollars, but when di Panaiotis kept postponing payment, Pittaco and his father decided to go to the French consulate to obtain payment from its protégé di Panaiotis. ${ }^{194}$

Manolaki di Panaiotis replied by stating that Pittaco had written almost nothing that was true and that he was ingrateful, and he disputed Pittaco's claim about the caution for the 1,00o lion dollars, for which he claimed there was no evidence. According to the French protégé, Pittaco was committing 'pure chicanery, deprived of all common sense' by claiming he had a caution for the 1,00o from both Manolaki di Panaiotis and Ağa Raz, which was not possible. ${ }^{195}$ For the 1,500, Pittaco should be grateful that it was thanks to di Panaiotis that he had managed to salvage 1,500 from the bankruptcy of Ağa Esse. If Pittaco did not want to buy the cochineal at the set prices, that was not di Panaiotis' problem, and he could not be held responsible for the lowering of the prices for cochineal on the market. It was, according to Manolaki di Panaiotis, a matter of Pittaco who 'complains about broth rich in fat', as the lower price of 2.5 lion dollars per ocque on the 50 di Panaiotis had offered would cause a loss of 125 lion dollars, which was better than the loss of 3 oo lion dollars on 1,0oo had he sided

192 NACs, $\mathrm{N}^{\circ} 324$, 'Antwoord van Panajotti Pittaco op het schrift van Manuel Kiriako di Panajotti', Izmir, 29/10/176o, '[...] subito o acetate la sua parola [...]'.

193 This was an Ottoman weight measurement and equalled about 1.284 kilograms. A.C. Barbier de Meynard, Dictionnaire turc-français (Paris, 1886), 2: p. 6o2; see also Jacques Savary des Bruslons, Dictionnaire universel de commerce (Copenhagen, 1765), p. 987.

194 NACS, $\mathrm{N}^{\circ} 324$, 'Antwoord van Panajotti Pittaco', Izmir, 29/10/176o.

195 NACs, $\mathrm{N}^{\circ} 324$, Replicq van Manuel Kiriako di Panajotti weeg: zijn proces met Panajotti Pittaco', Izmir, 13/11/176o, '[...] une chicane toute pure et depourveûe du bon sens [...]'. 
with the other creditors of Ağa Esse. ${ }^{196}$ Pittaco in turn labelled these claims as 'useless words without any true foundation', while his own declarations were substantiated by the Greek bishop and the three Greek merchants, Prasacachi, Vitale and Zingrilara, men 'who were known in the entire city.' ${ }^{197}$ He insisted on the 2,500 lion dollars plus the 116 of interest in a declaration made on 14 November and brought by the Dutch Chancellor Mann to the French consulate the same day. ${ }^{198}$ Di Panaiotis replied by demanding from Pittaco that 'he should once and for all produce either one or the other [referring to the Greek bishop's sentence and to the promissory note of Manolaki di Panaiotis] and all will be over [...] for good, that the said gentleman Pittaco would cease to blacken [meaning putting ink on] paper without use and that he [Pittaco] would take care to not file any requests with the court without having the documents authorising you to do so.'199 Pittaco retorted that the bishop's sentence had not been issued in writing, so he could not produce that document, but insisted that he had already provided the declaration of the witnesses. ${ }^{200}$ The legal discussion of the two Greek merchants thus centred around the production of written evidence, and di Panaiotis did not confirm or deny many of the claims made by Pittaco but decided to concentrate his defence on the claim that Pittaco had to prove di Panaiotis' responsibility in writing. It created a stalemate, and the case was taken to arbitration. ${ }^{201}$ The seventy-five ocques of cochineal that di Panaiotis wanted to give and that Pittaco did not want had already been deposed at the Dutch chancery in October 176o. In January 1761 it was decided that di Panaiotis had to take fifty of them back and pay 1,0oo,

196 NACs, $\mathrm{N}^{\circ} 324$, Replicq van Manuel Kiriako di Panajotti, Izmir, 13/11/176o, ‘[... si lamenta del brodo grasso [...]'. Comments on an earlier request (that has not been preserved) were made by di Panaiotis and registered at the French chancery on 28/10/176o.

197 NACs, $\mathrm{N}^{\circ} 324$, 'Request van Panajotti Pittaco aen den heere Boyer eerste Franse deputée, weeg: een differentie met sig: Manuel Kiriako di Panajottis', Izmir, 14/11/176o, '[...] parole inutile e senza verun fondamento $[\ldots]$ ' and '[...] da tutta la città pr tali cognosciuti [...]'. The French consul was out of town at the time, so the request was addressed to the first deputy.

198 NACs, $\mathrm{N}^{\circ} 324$, 'Request van Panajotti Pittaco', Izmir, 14/11/176o.

199 NACs, $\mathrm{N}^{\circ} 324$, 'Replicq van Manuel Kiriako di Panajotti aen Panajotti Pittaco', Izmir, 17/11/ 1760, ' [...] une fois pour toutes qu'il produise ou les unes ou les autres et tout sera fini [...] pour une bonne fois que le dit sr pitako cesse de noircir du papier inutilement $x$ qu'il fasse attention qu'on ne forme pas de demandes en justice lors qu'on na pas des titres qui vous y authorisent $[\ldots]$ '.

200 NACs, $\mathrm{N}^{\circ} 324$, 'Copije van een suplicq replicq van Panajotti Pittaco aen den eersten Franse deputé', Izmir, 19/11/176o.

201 No documents directly related to this arbitration were preserved in the Dutch consular archives. 
while Pittaco had to accept twenty-five at the price of twenty lion dollars each, making up the remaining 500. The other 1,000 would have to be collected by Pittaco at the French chancery, where di Panaiotis must have been instructed to depose them. ${ }^{202}$ Manolaki di Panaiotis did not intend to pay that last sum so easily, perhaps convinced he would be able to argue with French officials, as he was a French protégé. He had attempted the same with the Dutch, in vain, and two undated notes of his hand have been preserved at the Dutch consulate, both written to an official, probably the chancellor. In the first, he stated that he had brought the cochineal to the addressee and would send someone with the note, who would take the fifty ocque back. He also wrote that he did not want to see Pittaco at the chancery. In the second, he wrote that he thought Pittaco would go straight to the French chancery, and was hoping that he would not be received before di Panaiotis had the possibility to speak in person with the consul and the addressee of the note later the same day or the next. He wanted to ask about the interest and time period he would have to pay. ${ }^{203}$ It is unclear whether this personal approach had any success, but it seems unlikely.

The insertion of the earlier sentencing by the Greek bishop demonstrates the ease with which informal intracommunity judgment - a common practice since the Middle Ages - was also applied within an Ottoman-European context. ${ }^{204}$ At no moment was the legitimacy of the bishop's sentencing or his subsequent declaration questioned. The only element that was questioned was the nature of the sentencing, which had been communicated orally and not in writing. It might suggest an opposition between out-of-date community sentencing, with a Greek bishop adjudicating orally, and a modern, more rational sentencing necessitating written evidence. The contrast, however, is false and should be seen as a strategic attempt by di Panaiotis to challenge Pittaco's claim irrespective of the background of the system that had produced the sentencing.

\subsection{The Merchants' Style through Muslim Eyes}

Inspired by the institutional turn in analyses on the development of international trade and early modern capitalism, it has been argued that, while European legal instruments developed in such a way that they managed to

\footnotetext{
202 NACs, $\mathrm{N}^{\circ} 324$, 'Quitantie van M. Kiriako di Panajotti weegens den ontfang van 50 /o/ [ocques] couchenille uijt deese cancellerij', Izmir, 15/o1/1761; 'Quitantie van Panajotti Pittaco weegens den ontfang van 25 /o/ couchenille uijt deese cancellerij', Izmir, 16/o1/ 1761; and [Declaration about the payment of the 1,ooo lion dollars], Izmir, 16/o1/1761.

203 NACs, $\mathrm{N}^{\circ} 324$, two undated and unaddressed notes by Manolaki di Panaiotis.

204 See pp. 55-56 and $207-208$.
} 
support the expansion of international trade, Islamic legal systems did not undergo a similar evolution. In this view, Europe grew ever more exceptional, while the Ottoman Empire already went into decline after the sixteenth century - an interpretation not everyone adheres to. ${ }^{205}$ More recent research into the Ottoman legal context has demonstrated that such a juxtaposition is overly simplistic. Léon Buskens has argued that Islamic law was only one aspect of the legal context of the Ottoman Empire, next to state law and legal custom, which, van den Boogert contended, can be said to have included 'European'style legal practices, including merchant custom, through the legal privileges granted in the capitulations. ${ }^{206}$ Evidence has also shown the European fear of suffering avanias was based on a desire to hang on to the privileges that had been established in the capitulations. In their discourse on Ottoman justice, early modern European commentators neglected the intricacies of the Ottoman legal system, which prevented them from understanding the nature of the avanias properly. ${ }^{207}$ In his book on the functioning of the qadi courts of Çankırı and Kastamonu between $165^{2}$ and 1744, Ergene has asserted that, in spite of European assertions of corruption and unpredictability, 'we can identify a legal system with relatively concrete boundaries, pre-established procedure of litigation, and well-known evidentiary standards. ${ }^{208}$

Secondly, Europeans protested against some of the procedural practices upheld at Ottoman courts, such as restrictions to the submission of European written evidence and the lack of punishment for false statements, but they did not fundamentally question the Ottoman understanding of the most important adjudicating principle in commercial litigation, sentencing according

205 For the idea of Islamic underperformance, see Kuran and Lustig, 'Judicial biases in Ottoman Istanbul'; Timur Kuran, The long divergence. How Islamic law held back the Middle East (Princeton, 2011); 'Why the Middle East is economically underdeveloped: Historical mechanisms of institutional stagnation', Journal of economic perspectives, 18:3 (2004): pp. 71-90; and 'The Islamic commercial crisis: Institutional roots of economic underdevelopment in the Middle East', Journal of economic history, 63:2 (2003): pp. 414446. Opposing views were expressed in Pamuk, 'Institutional change and longevity of the Ottoman Empire'; as well as in Benjamin Braude, 'Christians, Jews, and the myth of Turkish commercial incompetence', in Relazioni economiche tra Europa e mondo islamico, secc. XIII-XVIII (Atti della trentottesima settimana di studi 1 - 5 maggio 2006, ed. Simonetta Cavaciocchi (Firenze, 2007), pp. 219-239. In Bryan S. Turner, 'Islam, capitalism and the Weber theses', British journal of sociology, 61:1 (2010): pp. 147-16o, the author deconstructs a number of Weberian ideas on the incompatibility of Islam and capitalism.

206 Léon Buskens, 'An Islamic triangle. Changing relationships between sharïa, state law, and local customs', ISIM newsletter, 5/oo, 8, consulted online at The capitulations, pp. 58-61.

207 See van den Boogert, The capitulations, pp. 155-157.

208 Ergene, Local court, p. 115. 
to the merchants' style. ${ }^{209}$ Declarations by Ottoman merchants and officials were accepted at the Dutch consular court, and it was not strange for expert statements to include signatures of Muslim traders. ${ }^{210}$ Europeans knew that Ottoman courts adjudicated commercial disputes - the capitulations even allowed for quarrels between European merchants to be settled at an Ottoman court. ${ }^{211}$ Not much is known about the actual functioning of a qadi court in the settlement of commercial disputes, but a few elements point to similarities with adjudication as it took place at the Dutch consular courts. It was common for the qadi to first attempt to settle matters amicably and informally, and the qadi judge seems to have often acted as arbitrator and mediator. ${ }^{212}$

Comparisons between European law and Islamic law regarding the role of individual rights generally make the point that, in the latter, individual rights (haqq) are subordinate to obligations (wäjib), an observation that has led to a rather negative perception on the less modern nature of Islamic law and its lesser adaptability to the requirements of international trade than western European models of law. ${ }^{213}$ In his work on Moroccan Islamic courts, Lawrence Rosen discussed the concept of haqq as an organising principle for networks of mutual indebtedness and obligation, networks in which individual legal persons could participate. ${ }^{214}$ While such concepts have contributed to the common reading of western concepts of 'rights' versus Islamic concepts of 'obligations', another interpretation is possible. In the context of early modern commercial litigation, Islamic concepts of mutual obligations and reciprocity as binding people together are easily reconcilable with the same concepts used in the merchants' style. The language and reasoning with which commercial disputes were adjudicated were not so different, it seems, from language and reasoning relying on haqq. While he does not make this point explicitly, Ergene,

209 See the contributions in Wolfgang Kaiser and Johann Petitjean, eds., 'Litigation and the elements of proof in the Mediterranean (16th-19th C.)', Quaderni storici, special issue, 3 (2016).

210 For an example of the signatures of Muslim traders on a declarations, see figure 8.

211 See p. 89.

212 Van den Boogert, The capitulations, p. 43.

213 Mohammad H. Kamali, 'Fundamental rights of the individual: An analysis of haqq (right) in Islamic law', American journal of Islamic social sciences, 10:3 (1993): pp. 340-366. The concept of haqq has several meanings, including 'established fact', 'right, power or claim', 'certainty or proof'. In the legal context, its primary meaning is 'truth' and reflects a positive assertion of an individual right, given by a lawgiver and attributable if it can be proven. Right of ownership, for instance, is a typical haqq, considered an exclusive assignment. Kamali, 'Fundamental rights', pp. 342-345.

214 Lawrence Rosen, The anthropology of justice. Law as culture in Islamic society (Cambridge, 1989), pp. $16-17$. 
using Rosen's insights, steers his analysis in a similar direction by arguing that 'if the main function of the court is the regulation of reciprocity among members of the community, as Rosen argues, then mediation and arbitration are the primary means to achieve it'.215 This quote could just as easily have been applicable to the nature of the European consular court system, whose task was essentially the same - considering the centrality of reciprocal interest in the concept of the merchants' style and the mechanisms that regulated the relationships between merchants.

While the consular court archives from Izmir do not contain litigations involving Muslim Ottomans, as such cases would have been brought before an Ottoman court, the archives of the consular court contain documents belonging to a debt affair that provides a glimpse into how one Muslim Ottoman attempted to obtain satisfaction for money owed to him. In 1765, Mehmed Araboğlu, a Muslim Ottoman gentleman who resided in Bergama, near Izmir, was owed 5 oo lion dollars by the Tuscan merchant Pietro Ferrieri. He accused the Tuscan of deceiving him by breaking his word and suggested this practice could have serious consequences, with 'no one trusting the Frankish nations to give them merchandise.'216 While Araboğlu claimed to have a great friendship with Consul Daniel Jean de Hochepied, he felt he also needed to insist on receiving his money back. 217

To obtain satisfaction, Araboğlu refused to release an obligation belonging to 'Capirossi', probably Orazio Gaetano Capirossi, Tuscan chancellor at the time. Araboğlu had also sequestered goods located in Çandarlı belonging to a Dutch merchant, Pieter Ouckama, and he had Ouckama's Jewish sensal arrested. ${ }^{218}$ This alarmed the Dutch consul, who made an effort to protect Ouckama's interests. Letters were sent back-and-forth, translated from and to Turkish, some of them given to a janissary named 'Ali Başa, who travelled between Izmir and Bergama, for delivery to Araboğlu. Several letters were sent to other persons in Bergama, who were thought to have an influence over Araboğlu, to try to convince him to release the sequestered goods as well as the sensal. ${ }^{219}$

\footnotetext{
215 Ergene, Local court, p. 193.

216 NACs, $\mathrm{N}^{\circ} 332$, 'Translaat copije der brieff van Arab Oglu met de janitsar Allj Bassa weegens d'affairen van Ouckama \& $\mathrm{C}^{\circ}$ aug: 1765 ', S.l., S.d., ‘[...] alla Nazione Franca nisuno non fida a dare mercanzie $[\ldots]$.

217 Ibid.

218 A sensal was a middleman in trade; see p. 78.

219 NACs, $\mathrm{N}^{\circ} 33^{2}$, 'Copije der brief int Turks geschreven aen Kútschuk Aga', Izmir, 11/o9/1765, 'Copije brief van de heeren consul assessooren en cooplieden van de Nederlandse natie aen Monsr Etienne in Sanderlk [Çandarlı near Izmir] weeg: d'affairen van de hn Ouckama \& $\mathrm{C}^{\circ}$ met Arab Oglu', Izmir', 11/o9/1765; and 'Copije translaet der brieff aen Arab Oglou met sig: Masgana', Izmir, [?]/11/1765.
} 
Ouckama had also contacted correspondents in Bergama, who explained that Ferrieri would need to pay or nothing could be done. Once Ferrieri reimbursed Araboğlu, all remaining issues between the Europeans could be settled in Izmir 'by way of justice and according to our capitulations, and who is in the wrong will pay the penalty' ${ }^{220}$ Central to the argument developed by the Dutch consul was that Araboğlu, in his attempt to obtain satisfaction, had resorted to a form of community responsibility: rather than taking Ferrieri to an Ottoman court, he had sequestered goods of subjects belonging to the same nation or at least he thought he had. Ferrieri was Tuscan, Capirossi as well, and the Tuscan merchants stood under protection of the Dutch consulate at the time, so for Araboğlu, they fell under the same jurisdiction as Ouckama, who was Dutch. In a reply to the Ağa of Çandarlı, who was thought to have influence over Araboğlu, the consul did not question the sequester as a means to obtain reimbursement in itself, but he argued that it was applied to the wrong person, 'as one [Ouckama] is Dutch and the other imperial [Ferrieri], one has nothing to do with the other and you, perfectly aware of the merchants' style for having dealt with many affairs, you know very well that this is not right'.221

In a letter sent the same day to a Frenchman in Çandarl, Consul de Hochepied, his assessors and the community of Dutch merchants of Izmir wrote that they had only suggested to Araboğlu to seek recourse to an Ottoman court so he could seek reimbursement through Ottoman adjudication on the basis of Ottoman equity. ${ }^{22}$ At no moment were Araboğlu or the Ağa of Çandarlı considered strangers to the informal laws and usages governing international trade. In letters addressed to them, terms such as equity and justice were mentioned, as well as the merchants' style, and the context or meaning was no different than when these concepts were used in a purely European context of litigation. When Araboğlu resorted to the common legal action of sequestering goods, he justified his actions with the principle of liability through collective responsibility, the mechanism in itself was not questioned by the Dutch diplomats. This might have been a strategic choice, as it was, admittedly, a bit outdated by the mid-eighteenth century, but forms of collective liability had

220 NACS, $\mathrm{N}^{\circ} 332$, 'Andrea Cardona aen dh: Ouckama in Smirne', Bergama, 14/08/1765, '[...] con via di giustizia e secondo nostre capitulationi, e chi avera torto paghera la pena [...]'.

221 NACS, $\mathrm{N}^{\circ} 332$, 'Copije der brief int Turks geschreven aen Kútschuk Aga', Izmir, 11/o9/1765, '[...] come l'uno [Ouckama] è olandese ed l'altro imperiale [Ferrieri], l'uno non a che fare con l'altro ed voi, cognoscendo perfettamente il stile mercantile pr aver trattato molti affari sapete molto bene, che questo non è giusto [...]'. Nominally, the Grand Duchy of Tuscany fell under the Holy Roman Empire, making Ferrieri indeed an imperial subject.

222 NACs, $\mathrm{N}^{\circ} 332$, 'Copije brief van de heeren consul assessooren en cooplieden van de Nederlandse natie', Izmir, 11/og/1765. 
not fully disappeared from commercial custom. ${ }^{223}$ The sequester of Ouckama's goods was questioned because of jurisdiction, not out of a fundamental misinterpretation of legal custom.

In the end, the sensal and Capirossi's obligation were released, but the sequester of Ouckama's goods remained unresolved. Ferrieri was given eight months to pay, in which time he hoped his uncle, arriving from Livorno, could ensure him the necessary funds. ${ }^{24}$ Muslim Ottomans, who could resort simply to Ottoman justice, were willing to communicate with European consuls on legality and the merchants' style, and they even adhered to similar mechanisms that had been in use to solve commercial disputes. Araboğlu showed, in the two letters he wrote and that were translated in Italian, that he was indeed fully aware of the merchants' style. He referred to name and reputation as very important commodities for traders. ${ }^{225}$ Ferrieri was equally aware of it, and he wrote a lengthy and secretive letter to a certain Andrea Cardona in Bergama, who had to deliver a message to Araboğlu for him, in which he asked to give him time to pay and to release Capirossi's and Ouckama's belongings. He also considered the debt 'a futility' ('una bagatella') and feared the actions of Araboğlu might lead to the end of all of Ferrieri's business in Christian lands, while, with a little bit of time, he could, with the assistance of friends, reestablish himself with more honour. ${ }^{226}$ It was a matter of commercial life or death for him, and Ferrieri realised that his name as well as his commercial reputation was at stake. ${ }^{227}$ The means that Araboğlu used affected Ferrieri's relationship with his diplomatic representative, de Hochepied, who apparently had threatened to throw Ferrieri in prison. Additionally, Ferrieri's inability to fulfil his obligations had negative consequences for his fellow traders.

While the letters pertaining to this quarrel preserved in the archives of the Dutch consulate of Izmir indicate that an agreement was reached, it still meant that Ferrieri had to pay and that Araboğlu had to wait. A second set of documents kept in the archives of the Dutch embassy in Istanbul suggests that

\footnotetext{
223 See pp. 207-208.

224 NACS, $\mathrm{N}^{\circ} 33^{2}$, 'Translaat copye der briefj van Araboglú aen den heere consul met sig. Masgana', [Bergama], 25/og/1765; and 'Translaat der Turkse brieff aan Araboglú met dhr Ouckama \& de can: Mann afgegaan', [Bergama], o3/10/1765. Araboğlu's frequent references to 'obligations', not just in the technical sense of a financial obligation but more generally as well, are reminiscent of the haqq concept discussed earlier.

225 NACs, $\mathrm{N}^{\circ} 332$, 'Translaat copije der brieff van Arab Oglu met de janitsar Allj Bassa weegens d'affairen van Ouckama \& $\mathrm{C}^{\circ}$ aug: 1765 ', S.l., S.d.

226 NACs, $\mathrm{N}^{\circ} 332$, 'Copije van een brief van P: Ferrieri aen Andrea Cardona in Bergamo', Izmir, $22 / 08 / 1765$.

227 Ibid.
} 
Araboğlu was not able to remain patient. About five months after the agreement with Ferrieri had been reached, a memorandum was sent to the Porte, which stated that the Ottoman was harassing Ferrieri, not letting him breathe, bringing the Tuscan to bankruptcy. Even though Araboğlu had been ordered by a ferman to keep quiet and wait for Ferrieri's payment, he had defied such orders by molesting the imperial vice-consul (Daniel Jean de Hochepied), the chancellor and Ferrieri, who was thrown in prison. Araboğlu even threatened to publicly disrepute the vice-consul. The memorandum, unsigned but in all likelihood written by someone at the imperial vice-consulate, probably in the name of the vice-consul, asked for a second ferman to control Araboğlu's actions. It reminded the sultan of the principle of reciprocity by stating that

I can assure the Sublime Porte that in Vienna, and in all of Germany, as well as in Hungary and Tuscany, many Turkish traders can be found, subjects of the Porte, amongst whom many are indebted to various German merchants, and some of them who cannot satisfy their debts flee, while others declare bankruptcy; but this does not mean that my Porte allows ours to attack other Turkish merchants or subjects of the Porte, to ask them reimbursement of the debts of those who fled or declared bankruptcy, as that would go against all the capitulations, and all justice, and our capitulations are reciprocal in all its articles, I am convinced that the Sublime Porte will not allow that his subjects act against the tenor of them and commit similar illicit excesses as those that the voivode of Bergama dares threaten to commit. ${ }^{228}$

The memorandum argues that forms of collective responsibility were indeed outdated and that rulers in Europe would not resort to such a mechanism.

228 NALT, $\mathrm{N}^{\circ}{ }_{1262}$ ('Affaire du négociant Ferrieri à Smyrne avec le voivode Arabzade de Pergame Dedel. NB tocca le affare di Smirne per Ferieri 1 iuglio 1766 '), 'Memoria alla fulgida Pte. Ottma., S.l., S.d., '[...] mentre posso assicurare la fulgida Porta, che tanto à Vienna ed in tutta la Germania, quanto in Hungaria e nella Toscana si trovano moltissimi mercanti Turchi, e suddite della Porta, frà li quali molti hanno contrattati debite con differente sudditi e mercanti Todeschi, e non potendo sodisfare li loro debiti sono parte fuggiti, parte falliti; mà non per questo la mia Porte hà permesso ai nostri, di atttaccare altri mercanti Turchi, o sudditi della Porta, per dimandare da loro il pagamento delle debiti dei fuggitivi o falliti, mentre questo sarebbe un agire contro le capitolazioni, ed contro ogni giustizia, e le nostre capitolazioni essendo reciproche in tutti li articoli, sono più che sicuro, che nemeno la fulgida Porta permetterà, che li suoi dipendenti agischino contro il tenore di quelle, e commettino simili illeciti Eccessi, delle quale ardisce minacciare il voivoda di Bergamo $[\ldots]$ '. 
While Araboğlu's actions can thus be considered not only as an infraction against the capitulations, a common argument used by European diplomats when trying to counteract Ottoman actions they felt were against the interest of their subjects, they can also be considered as violating the merchants' style in the sense that these actions can be interpreted as fitting within a mechanism of collective liability that in medieval times was an element of mercantile custom, but could no longer be considered as such in the second half of the eighteenth century. Araboğlu's actions should thus not be interpreted as belonging to a system unacquainted with or hostile to the merchants' style per se but should be seen as evidence that the content of the merchants' style is subject to change over time.

It seems only logical that the elements belonging to an international and informal set of customs used by merchants are disputed at times, which is part of the reason why adjudication was done by peers and relied on the use of turben in which peers explain what did belong to the merchants' style. But such mechanisms were harder to use in the Ottoman context, particularly considering the lack of use of European evidence. The Porte did, however, issue a second ferman in which Araboğlu's actions were condemned as going against all laws and rights, as well as against the tenor of the 'sacred capitulations. ${ }^{229}$ It would have pleased all adherents of the merchants' style to read that in justifying the ferman, one of the most essential characteristics of commercial custom was used: it was pointed out that Araboğlu had no right to seek satisfaction from Ferrieri through third persons, as he had 'put trust in the said merchants of his own spontaneous will. ${ }^{230}$ While the documentation belonging to one particular quarrel involving a Muslim Ottoman cannot serve as definitive evidence of Muslim adherence to the merchants' style, the reasoning used by all parties allows for the suggestion that Muslim Ottomans were willing to discuss disputes in terms dictated by the merchants' style.

229 NALT, $\mathrm{N}^{\circ} 1262$, 'Traduzione di fermano toccante il Ferieri', Istanbul, 30/06/1766, ‘[...] sacri capitolazioni $[\ldots]$ '.

230 Ibid., '[...] di sua spontanea volontà mise nel sudetto mercante confidenza [...]'. 